INTERNATIONAL MONETARY FUND
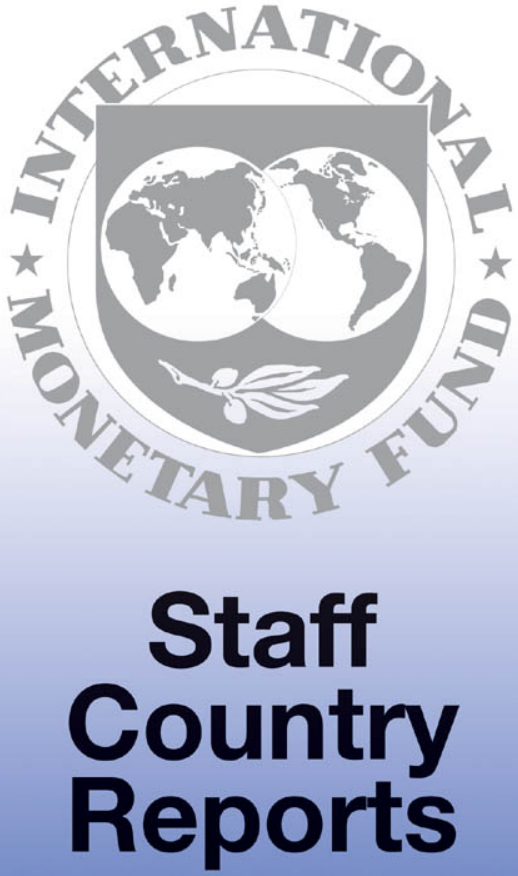


\section{Luxembourg: Selected Issues}

This Selected Issues paper for Luxembourg was prepared by a staff team of the International Monetary Fund as background documentation for the periodic consultation with the member country. It is based on the information available at the time it was completed on April 13, 2004. The views expressed in this document are those of the staff team and do not necessarily reflect the views of the government of Luxembourg or the Executive Board of the IMF.

The policy of publication of staff reports and other documents by the IMF allows for the deletion of market-sensitive information.

To assist the IMF in evaluating the publication policy, reader comments are invited and may be sent by e-mail to publicationpolicy@imf.org.

Copies of this report are available to the public from

International Monetary Fund • Publication Services

700 19th Street, N.W. • Washington, D.C. 20431

Telephone: (202) 6237430 • Telefax: (202) 6237201

E-mail: publications@imf.org • Internet: http://www.imf.org

Price: $\$ 15.00$ a copy

\section{International Monetary Fund \\ Washington, D.C.}




\section{INTERNATIONAL MONETARY FUND}

\section{LUXEMBOURG}

\section{Selected Issues}

Prepared by Francisco Nadal De Simone and Jean-Luc Annaert (EUR)

Approved by the European Department

April 13, 2004

Contents

Overview.

I. Trend Versus Cycle in Macroeconomic and Fiscal Developments

II. Pension System Projections and Policy Options ……………...................................24

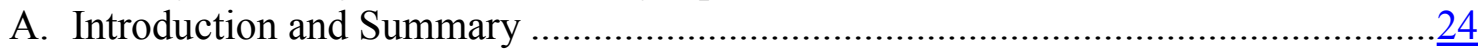

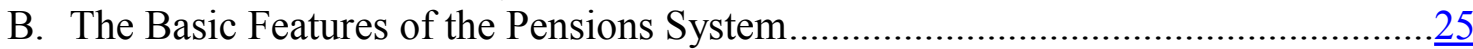

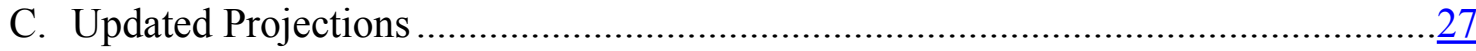

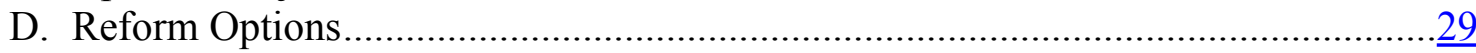

Boxes

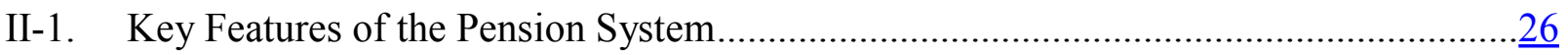

Tables

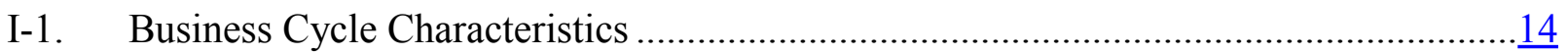

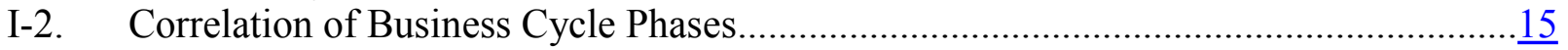

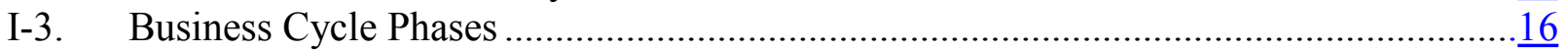

Figures

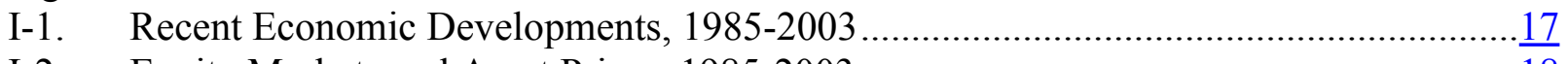

I-2. Equity Markets and Asset Prices, 1985-2003 ………...........................................18

I-3. Actual and Trend Real GDP Growth Rates, 1961-2002 ……....................................

I-4. Actual and Trend Labor Productivity Growth Rates, 1980-2002 ….............................20

I-5. Labor Market Developments, 1985-2003 …………................................................ 
I-6. Lead-Lag Relations: Asset Prices, Financial Sector, and

General Government Deficit, 1990-2002

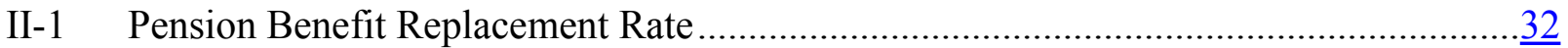

II-2. Population Aging and Crossborder Workers, 2003-2050 …......................................

II-3. The Ratio of Pensioners to Workers, 2003-2050 ........................................................

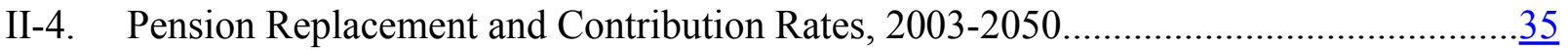

II-5. Pension Replacement and Contribution Rates, 2003-2050

Two Percent Real GDP Growth Scenario 


\section{Overview}

1. The current slowdown is unusually long, raising questions about the economy's growth potential and therefore also about prospects for the pension system. The Selected Issues papers study the economic growth performance of the past two decades with a view to shedding light on the growth prospects and fiscal implications. Furthermore, they discuss measures that could be taken to avoid a negative feedback between economic growth on the one hand and pension benefits and contribution rates on the other.

\section{Chapter I investigates whether the recent weakness in activity is largely} transitory or whether it heralds a new era of lower potential output growth. The economy's performance over 1980-2000 has been impressive, with real GDP growth averaging about $5 \frac{1}{2}$ percent per annum. However, potential output and labor productivity growth rates might be declining for about a decade already, by roughly one fifth percentage point per annum. While the estimates for potential output in 2002 still suggest a much higher growth rate than for the neighboring countries, this is no longer the case for potential labor productivity. At its current level, potential labor productivity growth might not be high enough to sustain, over a lengthy period, job creation and therefore output growth at much higher levels than in the surrounding countries. Regarding cyclical issues, the chapter finds that the recovery in equity prices over the past year can be expected to boost financial sector value added and real GDP growth. However, asset prices remain well below previous peaks and will continue to reverberate for several years in the economy. Over the medium run, fiscal revenues are thus unlikely to grow at the high rates of the past decade, also because they react with a lag to the weaker corporate profitability.

\section{Chapter II explains one option for reforming the pay-as-you-go pension pillar,} which is to link pension benefits to the contributions base through a "solidarity factor," as argued in the accompanying staff report (SM/04/113, 04/07/04, Box 3). Long-run pension projections suggest that the present income replacement and contribution rates are jointly sustainable only if real GDP growth averages about 5 percent per annum. ${ }^{1}$ However, by (i) formally linking pension benefits to developments in the contributions base through the "solidarity factor," and (ii) simultaneously linking the statutory retirement age to life expectancy, relatively generous income replacement rates could be sustained over the long run, even with, by historical standards, relatively low real GDP growth. More importantly, these measures would signal economic agents that contribution rates would be kept in check even as the population ages or as the economy suffers shocks. This signal would help sustain the inflow of capital and workers and thereby forestall potentially more drastic measures in the future. Furthermore, the chapter argues that the "solidarity factor" can ensure a more gradual adjustment in replacement and contribution rates than the present system, which relies on reevaluations and, if deemed necessary, adjustments of these rates every seven years.

${ }^{1}$ See IMF Staff Country Reports No. 02/118, Box 1. 


\section{Trend Versus CyCle in Macroeconomic ANd Fiscal DeVelopments 2}

\section{A. Introduction and Summary}

4. The current slowdown is unusual in terms of its depth, duration, and the role of the financial services sector (Figure I-1). Real GDP growth has fallen to about 11/4 percent starting 2001, from an average growth rate of 51/2 percent during 1980-2000. The last period of similarly sluggish activity was around the period of the world cycle trough of 1981 . Neither around the world cycle trough of 1991, nor around the European cycle trough of 1993 did Luxembourg's annual real GDP growth ever fall below 31/4 percent. $^{3}$ At the sectoral level, the weakening of value added has been broad based but particularly pronounced in financial services, driven by the correction in global equity markets. Real value added in this sector shrank for the first time since 1985, reflecting the fall in stock-market valuations-by about 60 percent between September 2000 and April 2003-according to the euro-area Dow Jones index (Figure I-2). Given the economy's large exposure to financial services, real GDP growth has thus fallen more than in other euro-area countries.

5. Not surprisingly, the budgetary situation has also deteriorated significantly. For the first time in two decades the general government budgetary balance is estimated to have recorded a deficit, equivalent to about 1 percent of GDP in 2003, although tax revenue has yet to reflect the full effect of the economic slowdown. This follows surpluses averaging $4 \frac{1}{2}$ percent of GDP during the boom years of 1998-2000. Furthermore, budgetary deficits are now projected to persist well into the second half of the decade, still reaching $1 \frac{1}{2}$ percent of GDP in 2006, according to the authorities' latest Stability and Growth Program (SP) update.

6. A key issue is whether the recent weakness in activity is largely transitory or whether it heralds a new era of lower potential output growth. Identifying changes in trend (potential) growth early and accurately is of fundamental importance for adjusting policies in a timely manner. Accordingly, this chapter attempts to decompose recent output developments into their trend and cycle components and explores some fiscal implications. The main findings are that both structural and cyclical factors are at play in the current growth slowdown, with output and productivity trend growth rates declining already for some time. While the recent recovery in equity prices-by some 30 percent since April 2003 - can be expected to boost financial sector value added and real GDP growth, asset prices remain well below previous peaks and will continue to reverberate for several years in the economy and the public sector accounts.

${ }^{2}$ Prepared by Francisco Nadal De Simone.

${ }^{3}$ This is the case according to the (most reliable) ESA 95 data. The ESA 79 data series stretches from 1995 back to 1960 and, in some charts, has been spliced with the ESA 95 for 1996-2002. ESA 79 data show low growth rates for a few years in the 1990s but not for three years in a row, as is the case currently. 
7. The remainder of the paper is organized as follows. Section B reviews recent output developments, distinguishing between cyclical and structural components but focusing on the latter; Section C analyzes the cyclical component in more detail; and Section D concludes.

\section{B. Recent Macroeconomic Developments: Trend versus Cycle}

\section{Various methods can be used to decompose output developments into trend and} cycle components. One approach develops a structural model of the economy to separate trend and cycle components of output changes. Such a model might assume that cyclical changes are caused mainly by demand-side shocks while trend changes are caused mainly by supply-side shocks (e.g., Blanchard and Quah, 1989). Another approach eschews assumptions about the structure of the economy and instead decomposes actual output into permanent and transitory movements using univariate statistical techniques. This is the approach that is adopted here because it is relatively simple to apply, parsimonious on the assumptions that it imposes, and well-suited to a very open economy such as Luxembourg.

\section{Output trend developments are less stable for small economies than for large} economies. The reason is that various supply-side shocks concern small economies more, notably domestic and foreign changes in taxation and regulation as well as shifting locational preferences and opportunities of economic agents. More importantly, in small, open economies such shocks are likely to interact in a reinforcing manner: for example, changes in regulation can dampen financial sector and output growth which, in turn, reduces migration, with further output losses. Both vicious and virtues growth circles are possible. These circles are difficult to model. As a partial remedy to the issues raised by migration, this section scrutinizes separately the trend developments in output and labor productivity growth.

\section{Among the univariate statistical measures to decompose output the Ouliaris} ideal band-pass filter (2001) has several advantages over other methods. Output changes may be driven by many processes, some operating at irregular or very high frequencies (e.g., seasonal cycles), others at an intermediate frequency (business cycles), and some at a low frequency (changes in trend growth rates). The fundamental idea of univariate methods is to decompose the processes into these three components using a filtering procedure. Filters typically assume a business cycle length of anywhere between 2 to 8 years. The Ouliaris filter has several advantages over other filters.

- Unlike other filters (e.g., Hodrick and Prescott, 1997), the Ouliaris filter operates entirely in the frequency domain.

- Unlike the Baxter and King (1999) band-pass filter, the Ouliaris filter is not affected by leakage from the zero frequency component of nonstationary series, nor does it involve a loss of observations at either end of the series-for policymaking, recent data are particularly important.

- The Ouliaris filter is less likely to introduce spurious cycles, which is a particular problem with the Hodrick-Prescott filter. The smoothing usually applied by 
practitioners assumes that the series under investigation shares the statistical properties of U.S. time series on which the Hodrick-Prescott filter was based.

- The Ouliaris filter is statistically consistent, unlike the Baxter and King filter, and does not suffer from end-of-sample bias, unlike the standard Hodrick-Prescott filter.

\section{Ouliaris filter estimates suggest that the potential output growth rate of the} Luxembourg economy might be about 4 percent per annum but that has been declining over the past decade (Figure I-3). An estimate of recent potential output growth based on the 1960-2002 ESA 79/95 spliced time series is about 4 percent; based only on the 19812002 ESA 95 data it is close to 5 percent. However, given the variance that supply-side shocks introduce into estimates of potential output — as shocks to productivity interact with migration or commuting in a reinforcing manner - it might be more appropriate to focus on the average estimate for potential output growth over several decades. Both for the spliced 1960-2002 ESA 79/95 and the 1981-2002 ESA 95 time series average potential growth rate amounts to about 4 percent. Nonetheless, a cause for concern is that potential output growth has declined by about one fifth (ESA 95 data) to one quarter (ESA 79 data) percentage point per annum since the peaks reached in the late 1980s or early 1990 s.

\section{The slowdown in output trend growth is mainly driven by labor productivity} trend growth and there is no compelling evidence for a sustained turnaround thus far (Figure I-4). ${ }^{4}$ During 1981-2002, labor productivity trend growth averaged about 21/2 percent. However, after reaching a peak of about $3 \frac{1}{2}$ percent in 1989 , it has been decelerating to around $1 \frac{1}{3}$ percent recently. Like real GDP trend growth, labor productivity trend growth fell during the $1990 \mathrm{~s}$, on average by one fifth percentage point. ${ }^{5}$ Therefore, most of the drop in potential output growth seems to be due to labor productivity.

\section{The decrease in labor productivity trend growth in Luxembourg is not shared to} a similar extent by neighboring countries. The trend growth differential between Luxembourg on the one hand and Belgium, France, and Germany on the other averaged about $3 / 4$ percentage points per annum during 1981-2002 (Figure I-4). However, it peaked at about $1 \frac{1}{4}$ percentage points in 1989 and has since almost vanished.

\section{The deceleration of labor productivity is likely driven by total factor}

productivity (TFP). The reason is that during the 1990s the average annual growth rate of fixed capital formation was a healthy 9 percent, relative to real GDP growth of about $6 \frac{1}{4}$ percent. IMF (2002) concluded that there was a deceleration of TFP growth in

\footnotetext{
${ }^{4}$ Consistent employment data back to the 1960s has not been available and thus productivity is analyzed only with the ESA 95 data series.

${ }^{5}$ Average labor productivity growth was 1.4 percent during the period 1993-2002 while trend growth in labor productivity was 1.7 percent.
} 
Luxembourg in the second half of the 1990s which seemed to have affected mostly the nonfinancial sector. However, the slowdown has now also spread to the financial sector, where average TFP growth declined to $1 \frac{1}{2} 2$ percent per annum in 1996-1999 against $2 \frac{1}{4}$ percent per annum in the first half of the 1990s.

\section{The decline in TFP growth might be caused by changes in the regulatory} environment or might reflect a maturing of the financial services industry. Changes in the regulatory environment are difficult to pinpoint, although the regulatory burden on the financial services sector certainly has not decreased. Falling returns to learning - consistent with an Aghion and Howitt (1999) learning by doing (LBD) endogenous growth modelmight be a more promising explanatory factor. Luxembourg grew out of the steel crisis helped by the rapid development of a strong financial sector during the second half of the 1970 s and the first half of the 1980s. Initially, LBD capitalized on institutional-policy advantages in a strongly competitive environment, driving TFP growth. But as the financial sector gained market share and matured, the relative importance of capital and labor in the production process increased, while that of LBD and TFP growth diminished. Moreover, the fall in the rate of firms entry in the financial industry might be another force driving the drop in the trend growth rate of the financial industry. ${ }^{6}$

\section{Labor force growth has supported output trend growth strongly thus far,} suggesting that the slowdown in productivity has not had an obvious effect on migration and commuting. Population growth accelerated from 0.3 percent per annum in the 1980 s to 1.4 percent per annum during 1990-2002; over the same period, domestic employment growth accelerated from an annual average rate of 1.4 percent to an annual average of 3.6 percent (Figure I-5), driven by a rising number of commuters. This rapid expansion of employment likely was related to relatively prudent wage setting as real unit labor costs mostly declined.

\section{However, the rising unemployment among residents and the recent lack of wage} moderation are causes for concern (Figure I-5). The wage moderation did not carry through the latest slowdown, as real unit labor costs rose significantly in 2001 and 2002. Given that the economy is open and small, and thus a price taker in a global market, it is unlikely that unit labor costs can rise significantly without denting corporate profitability and competitiveness. A further concern is the secular increase in structural unemployment, from 1.4 percent in the 1980 s to about double that amount recently. While the structural unemployment rate might appear low in a European context, the actual unemployment rate

\footnotetext{
${ }^{6}$ According to this LBD model in the Schumpeterian tradition, growth depends on the mix of research and development $(\mathrm{R} \& \mathrm{D})$ and LBD. LBD improves the quality of products, and this is fully internalized by the firm because only the firm that solves practical production problems benefits from the experience. As in other Schumpeterian models, an increase in the real interest rate reduces growth via a reduction of R\&D. Similarly, growth falls if the rate of entry of new firms or products declines. The real interest rate, however, has not trended up.
} 
stands already at about $4 \frac{1}{2}$ percent and a wider definition of unemployment that includes people on subsidized work schemes and training is close to 6 percent.

\section{Rising actual unemployment is likely to translate into higher structural} unemployment because of various institutional features of the labor market, which also explain the coexistence of healthy employment growth and rising unemployment. In particular, the high replacement rate of unemployment benefits, the fairly broad targeting of those benefits (younger workers need only little work experience to obtain benefits and older workers can receive support for up to 2 years), the eligibility conditions and unlimited duration of minimum income support (RMG), and the frequent recourse to early retirement tend to make domestic workers more expensive relative to commuters. Thus, healthy employment growth can be flanked by rising unemployment because commuters have lower reservation wages than residents. ${ }^{7}$ Furthermore, with unemployment of residents not projected to fall significantly through 2006, a future re-estimation might reveal a ratcheting up of structural unemployment that is not yet apparent in 2002-03 data. The reason is that once residents lose employment, the incentives to accept a job fall over time: skills and therefore attainable wages depreciate, while jobless support is generous and long lasting.

\section{Overall, both output trend growth and labor productivity trend growth have} been declining but remain at levels that suggest that much of the recent economic slowdown is cyclical. The latest estimate for potential output growth is at least 4 percent per annum, relative to actual growth rates of about 11/4 percent in 2001-03; for potential labor productivity growth it is around $1 \frac{1}{3}$ percent, relative to a significant actual productivity decline in 2001-03. The difference between output and labor productivity is labor force growth of about $2 \frac{1}{2}$ percent annually, driven by migration and commuting.

\section{The key issue is whether migration and commuting will be high enough to} combine with the relatively low labor productivity trend growth rate to continue to produce trend output growth of 4 percent annually. Modeling the interaction between output growth and migration or commuting is difficult. The evidence in the literature on migration would suggest that as productivity trend growth declines and unemployment rises, the expansion of the labor force should decelerate as well, further lowering output trend growth. This feedback has not been considered in the estimation of potential output growth presented here, because of the absence of standard methodologies to do so. But the important point is that policies can limit any such feedback, for example, by avoiding tax and contribution rate increases as well as rising structural unemployment. ${ }^{8}$

\footnotetext{
${ }^{7}$ Another reason is the need to import skills that are unavailable locally.

${ }^{8}$ Notice that congestion is a potential concern with respect to employment growth but the example of the large metropolitan areas in the world and of other, small open economies suggests that Luxembourg is still far away from hitting any major, natural long-term constraints.
} 


\section{Business Cycle Characteristics}

\section{This section studies the business cycle characteristics of various economic} variables. Using, for example, real GDP growth, the definition of business cycle statistics is as follows. The duration of a cycle is the number of periods between two consecutive peaks (or troughs) of growth rates. The amplitude or deepness of a recession is the growth contraction from peak to trough in percentage points, and mutatis mutandi, for the amplitude of an expansion. Steepness is the rate of change of output growth from peak to trough, or vice versa. Cumulative movements of output growth are the output losses from peak to trough relative to the previous period. As cumulative movements of output are approximated using a linear procedure, a measure of the excess in cumulated movements is also presented.

\section{The section also looks at neighboring countries, given the role Luxembourg} plays as a European financial center. Accordingly, indicators of economic and financial activity for the euro area, Belgium, France, Germany, the United Kingdom, and the United States are also included. The sample period covers 1980-2002, but data for fiscal variables for Luxembourg are only available on a consistent basis starting in 1990 (see Data Sources), which limits the robustness of the conclusions and poses problems for obtaining significant results in some circumstances.

\section{The methodology for determining business cycle characteristics avoids any} simple detrending or filtering to avoid altering the statistical properties of the cycle. It is therefore not directly comparable to other work that dates cycles based on deviations from fixed sample means (e.g., Jaeger and Schuknecht, 2003). The main reason for this strategy is to avoid altering the statistical properties of the cycle (King and Rebelo, 1993 and Harding and Pagan, 2002). A local peak in the Harding and Pagan (2002) methodology that is adopted here requires $y_{t}-y_{t-2}>0, y_{t}-y_{t-1}>0, y_{t+1}-y_{t}<0$, and $y_{t+2-}-y_{t}<0$ with the y series either in levels or in rates of change. Given that this paper is mostly interested in growth developments, the $y$ series is in rates of change, unless otherwise noted.

24. The key features of peak to trough (PT) and trough to peak (TP) developments suggest (Table 1):

- $\quad$ The duration of cycles in real asset prices is much longer than the duration of cycles in real output. The duration of cycles in Luxembourg output and fiscal variables is similar, between 5-6 years. ${ }^{9}$ Cycles in real value added in the financial

\footnotetext{
${ }^{9}$ Possibly due to the lack of full synchronization among the cycle phases of euro-area countries, the duration of the euro-area real GDP growth cycle is much longer than the duration of the Luxembourg real GDP growth cycle. Nadal-De Simone (2002) contains a description of business cycle characteristics of real GDP both in levels and in growth rates for France, Germany, Italy, and the United States. The duration of those countries' cycles is about 3 years.
} 
sector (i.e., fees and commissions) appear roughly as long as cycles in real asset prices (BEDEFR), lasting about 10 years. ${ }^{10}$

- Cycles in real output and fiscal variables are asymmetric, meaning that developments during the PT phase cannot simply be viewed as a mirror image of developments during the TP phase. ${ }^{11}$ In particular, contractions are shorter and steeper than expansions, a characteristic that is very pronounced for real revenue growth. Cycles of financial variables are considerably less asymmetric.

- The amplitudes of cycles in financial variables and in real revenue growth are much larger than the amplitude of cycles in real activity.

- $\quad$ Real GDP growth exhibits strong early output expansions, as has been found for U.S. real GDP growth. ${ }^{12}$ This is reflected in the positive value of the "excess" statistics during the upswing phase. Real revenue growth shares this feature.

\section{Further analysis reveals the cross correlation among business cycle phases of} real GDP, fiscal variables, and financial variables. Here cross correlations between economic time series refer to cross correlations between their estimated cycle phases, i.e., cross correlations between time series' upswing (TP) and downswing (PT) phases, determined according to the Harding and Pagan (2002) methodology. Significant contemporaneous correlations include those between phases of (Table 2): (i) real GDP and real revenue growth; (ii) real GDP growth in Luxembourg and the euro area; (iii) real value added of Luxembourg's financial sector and the euro-area Dow Jones equity market index; ${ }^{13}$

${ }^{10}$ See also Jaeger and Schuknecht (2003) and Bernanke, Gertler, and Gilchrist (1999) for similar results. Here, the average cycle length for average real asset prices growth in Belgium, France and Germany (referred to as BEDEFR on Table 1) is 10 years; it is about 9.5 years if the UK and the US real asset prices are included (referred to as "World"). Notice that the index combines three different asset classes, equities, residential property, and commercial property, weighed using the shares of each component in private sector wealth; the private consumption deflator is used to convert nominal to real price indices. Data were kindly provided by Jaeger. Results on real asset prices in levels (not shown) are similar to those for asset prices in growth rates.

11 The considerable asymmetry in cycles in real economic activity is a well-known result in the literature. The literature on output asymmetry is vast and can be traced back to early references in Keynes (1936). More recent work includes the seminal piece by Neftcy (1984), as well as Seichel (1993), Ramsey and Rothman (1996), and Razzak (2001).

12 See Kim (1999).

${ }^{13}$ Cycle phases of real value added in the financial sector might not exhibit a strong, positive correlation with phases of real asset prices because lending for personal or corporate real 
(iv) the general government balance-to-GDP ratio on the one hand and the euro area real GDP growth and real asset price growth in neighboring countries on the other hand; and (v) world real asset prices and both real asset prices in neighboring countries and the Dow Jones equity market index. ${ }^{14}$ Furthermore, lead-lag tests of cross correlations between business cycle phases reveal that equity prices (DJEUROGA) lead asset prices (WORLD) for two to three years (Figure I-6); and that financial sector value added (FSRG) leads the general government balance-to-GDP ratio (GGGDP) for up to two years.

\section{The current downswing is unusual also because of the extent of asset price} weakness, which will continue to reverberate for some time (Table 3). Recently, all important variables were in a downswing phase, including real GDP growth both in Luxembourg and the euro area, financial sector value added, equity and asset prices, and real revenue (Table 3 ). Given the close contemporaneous relation between equity prices and financial sector value added, the recent recovery of equity prices can be expected to boost financial sector activity and, with some lag, also to improve the public sector accounts. Past experience would suggest that the recovery could be fairly strong early on but the current setting is unusual. Furthermore, considering the extent of the fall in equity prices since their peak, output and real revenues will likely grow at a more moderate pace than in the 1990s.

\section{A fundamental issue is how the asymmetries in the real GDP cycles and the large amplitudes of asset price cycles should be taken into account in setting fiscal policy.} Contractions are short while expansions are long, sending potentially confusing signals about trend output and therefore revenue growth rates. Furthermore, during asset price booms revenues might appear stronger than they fundamentally are. Conversely, during periods of asset price corrections, declines in the revenue-to-GDP ratio would not be surprising: the amplitude of real revenue cycles is much larger than that of real GDP cycles. Fiscal policy needs to take this into account and, considering also the length of asset price cycles, take a cautious approach in determining expenditure policy, using a planning horizon that stretches perhaps further into the future than is currently the case. ${ }^{15} \mathrm{~A}$ deeper analysis of the implications of asymmetries in cycles and equity prices for the design of various fiscal rules lies beyond the scope of this paper.

estate accounts only for a small proportion of the activity of Luxembourg banks - more than two thirds of their exposure is to other financial institutions.

${ }^{14}$ With cycle phases of Luxembourg real GDP growth or real revenue growth the relation of the phases in the general government balance (in percent of GDP) is positive but insignificant. This might reflect that (particularly capital) expenditure has been expanded in line with GDP, notably to alleviate constraints on growth.

${ }^{15}$ The end of the planning horizon of the current Stability and Growth Program is 2006. 


\section{Conclusion}

\section{The main findings are that both cyclical and structural factors play an} important role in the current growth slowdown and that, in setting policies, past output and fiscal revenue growth rates should therefore not be extrapolated. The unusually long period of sluggish activity renders estimates of output trend growth very uncertain. An estimation methodology that counts among the most robust to "end-point-problems" reveals that potential output and labor productivity growth have been declining by at least one fifth percentage point per annum over the past decade. While the economy's potential output growth rate remains high relative to that of neighboring countries, this is no longer the case for the potential labor productivity growth rate. As productivity slows, so could job creation, wage growth, and therefore the expansion of the labor force, with adverse consequences for potential output growth.

\section{One important caveat to bear in mind is that potential output growth estimates} need to be treated particularly cautiously for Luxembourg; and they should not be used to gauge the amount of slack in the economy. It might be sensible to talk about the existence of a potential output growth rate over the medium run but less so over the long run. The reason is that the labor force variable cannot be considered sluggish over a long horizon. Other reasons for treating potential output growth estimates with care also relate to the openness of the economy, notably its sensitivity to domestic and foreign changes in taxation and regulation and to shocks to the demand for financial services. Furthermore, given the relation between commuting and migration on the one hand and economic conditions on the other, output gaps cannot be reliably gauged.

30. The characteristics of the latest economic slowdown are unusual, notably because of the extent of asset price weakness, which will continue to reverberate for some time. Typically, Luxembourg experiences strong output expansions in the recovery phase. The upswing in equity prices over the past year is consistent with such a scenario. However, the latest slowdown is characterized by weak real GDP growth, sluggish financial sector value added, and an unusually large correction in equity prices from previous peaks. This points to a slower recovery and likely will forestall a return to the real GDP growth rates of the 1990s barring another, unusual acceleration of equity prices. Since the general government budgetary balance continues to react over several years to slowdowns in value added of the financial sector, probably reflecting partly the lag with which corporate taxes are collected, further fiscal weakness can be expected for some time. Also, a return to the tax revenue growth rates of the 1990s appears unlikely. 


\section{Data Sources}

All data are annual. The data on Luxembourg are from STATEC, the Luxembourg statistical office. Euro-area real GDP is from Eurostat. DJ Euro Stoxx data is from Bloomberg. Real asset prices are from Jaeger and Schuknecht (2003). Data generally cover the following periods (acronyms in parentheses):

Real GDP (GDPG), real value added in the financial sector (FSRG), euro area GDP (EUROAG), and Belgium-France-Germany real asset prices (BEDEFR), US real asset prices (US) and World real asset prices (WORLD): 1980-2002.

DJ Euro Stoxx (DJEUROGA): 1987-2002.

Central government balance and general government balance to GDP (CCGDP and GGGDP, respectively), central government revenue (RG): 1990-2002.

Central government revenue cash (RGC): 1980-2002.

The deflator for revenues is the GDP deflator. 
Table I-1. Luxembourg: Business Cycle Characteristics

(In percent, unless otherwise indicated)

\begin{tabular}{|c|c|c|c|c|c|c|c|c|c|c|}
\hline & \multicolumn{5}{|c|}{ Luxembourg } & \multirow[b]{2}{*}{ Euro area } & \multirow[b]{2}{*}{ BEDEFR 3/ } & \multirow[b]{2}{*}{ U.S. } & \multirow[b]{2}{*}{ "World" 4/ } & \multirow{3}{*}{$\begin{array}{c}\text { Euro area } \\
\text { Dow Jones } \\
\text { index 5/ }\end{array}$} \\
\hline & \multirow[b]{2}{*}{ Real GDP 1/ } & \multirow{2}{*}{$\begin{array}{c}\text { Real } \\
\text { financial } \\
\text { sector 1/ }\end{array}$} & \multirow{2}{*}{$\begin{array}{c}\text { Central } \\
\text { government } \\
\text { balance 2/ }\end{array}$} & \multirow{2}{*}{$\begin{array}{l}\text { Central } \\
\text { government real } \\
\text { revenue } 1 /\end{array}$} & \multirow{2}{*}{$\begin{array}{c}\text { General } \\
\text { government } \\
\text { balance 2/ }\end{array}$} & & & & & \\
\hline & & & & & & Real GDP 1/ & \multicolumn{3}{|c|}{ Real asset prices $1 /$} & \\
\hline \multicolumn{11}{|c|}{ Mean duration (years) } \\
\hline PT & 2.5 & 5.0 & $\ldots$ & 2.0 & 2.0 & 5.0 & 5.0 & 4.0 & 4.5 & $\ldots$ \\
\hline $\mathrm{TP}$ & 3.5 & 6.0 & 8.0 & 5.0 & 3.0 & 7.0 & 5.0 & 4.3 & 5.0 & $\ldots$ \\
\hline \multicolumn{11}{|c|}{ Mean amplitude } \\
\hline PT & -6.0 & -12.6 & $\ldots$ & -15.4 & -0.9 & -4.4 & -10.8 & -9.9 & -11.1 & $\ldots$ \\
\hline $\mathrm{TP}$ & 5.5 & 9.7 & 4.7 & 9.8 & 3.5 & 3.8 & 11.8 & 17.9 & 13.7 & $\ldots$ \\
\hline \multicolumn{11}{|c|}{ Steepness } \\
\hline PT & -2.4 & -2.5 & $\ldots$ & -7.7 & -0.5 & -0.9 & -2.2 & -2.5 & -2.5 & $\ldots$ \\
\hline TP & 1.6 & 1.6 & 0.6 & 2.0 & 1.2 & 0.5 & 2.4 & 4.2 & 2.7 & $\ldots$ \\
\hline \multicolumn{11}{|c|}{ Cumulation } \\
\hline PT & -7.9 & -18.0 & $\ldots$ & -17.1 & -1.3 & -9.2 & -24.4 & -17.9 & -26.2 & $\ldots$ \\
\hline $\mathrm{TP}$ & 11.4 & 24.3 & 21.2 & 32.5 & 4.6 & 18.9 & 27.4 & 25.5 & 35.5 & $\ldots$ \\
\hline \multicolumn{11}{|c|}{ Excess } \\
\hline PT & 0.1 & 2.7 & $\ldots$ & -0.8 & -0.2 & 0.4 & 72.8 & 0.6 & -4.6 & $\ldots$ \\
\hline $\mathrm{TP}$ & 0.4 & -0.8 & 0.3 & 1.6 & -0.3 & 0.8 & -7.3 & -1.4 & 23.5 & $\ldots$ \\
\hline
\end{tabular}

Sources: IMF, WEO; Datastream; Jaeger and Schuknecht (2003); and IMF staff estimates. PT stands for Peak-to-Trough and TP for Trough-to-Peak.

1/ Annual growth rates.

2/ Ratio to GDP.

3/ Refers to Belgium, France, and Germany real asset prices average.

4/ Refers to BEDEFR plus the U.K. and U.S. real asset prices average.

5/ Cycles could not be statistically identified because of the short sample. 


\section{Table I-2. Luxembourg: Correlation of Business Cycle Phases 1/}

(Growth rates, except for general government balance)

\begin{tabular}{|c|c|c|c|c|}
\hline \multicolumn{3}{|c|}{ Luxembourg } & BEDEFR 2/ & "World" 3/ \\
\hline Real GDP & $\begin{array}{l}\text { Real value added } \\
\text { in financial sector }\end{array}$ & $\begin{array}{l}\text { General govt. } \\
\text { balance to GDP }\end{array}$ & Real ass & t prices \\
\hline
\end{tabular}

Real GDP

Real value added in financial sector

General government balance to GDP

Central government real revenue

Euro area real GDP

BEDEFR 2/

Real asset prices

"World" 3/ 1.00

Real asset prices

Euro area

Dow Jones index

$0.85 *$
1.00

1.00

$0.38 * *$

$0.85 *$

$0.71 *$

1.00

$0.68 *$ 1.00

$0.78 *$

Sources: IMF, WEO; Datastream; Jaeger and Schuknecht (2003); and IMF staff estimates.

$1 /$ Only significant estimates are shown (* refers to 95 percent significance and ** to 90 percent significance).

2/ Refers to Belgium, France, and Germany real asset prices average.

3/ Refers to BEDEFR plus the U.K. and U.S. real asset prices average. 
Table I-3. Luxembourg: Business Cycle Phases 1/

Peaks and Troughs $(1=$ yes; $0=$ no $)$

\begin{tabular}{|c|c|c|c|c|c|c|c|c|c|c|c|c|c|c|c|c|}
\hline & \multicolumn{2}{|c|}{ Real GDP } & \multicolumn{2}{|c|}{ Fin. sec. real value added } & \multicolumn{2}{|c|}{ Euro area real GDP } & \multicolumn{2}{|c|}{ Euro area Dow Jones 2/ } & \multicolumn{2}{|c|}{ BEDEFR asset prices 4/ } & \multicolumn{2}{|c|}{ World asset prices 5/ } & \multicolumn{2}{|c|}{ GG balance/GDP 3/ } & \multicolumn{2}{|c|}{ Central govt. revenue } \\
\hline & Peaks & Troughs & Peaks & Troughs & Peaks & Troughs & Peaks & Troughs & Peaks & Troughs & Peaks & Troughs & Peaks & Troughs & Peaks & Troughs \\
\hline 1987 & 0 & 0 & 0 & 0 & 0 & 0 & 0 & 0 & 0 & 0 & 0 & 0 & & & & \\
\hline 1988 & 1 & 0 & 0 & 0 & 1 & 0 & 0 & 0 & 0 & 1 & 0 & 0 & & & & \\
\hline 1989 & 0 & 0 & 1 & 0 & 0 & 0 & 1 & 0 & 1 & 0 & 0 & 0 & & & & \\
\hline 1990 & 0 & 1 & 0 & 0 & 0 & 0 & 0 & 0 & 0 & 0 & 0 & 0 & 0 & 0 & & \\
\hline 1991 & 0 & 0 & 0 & 1 & 0 & 0 & 0 & 1 & 0 & 0 & 0 & 0 & 0 & 0 & 0 & 0 \\
\hline 1992 & 0 & 0 & 1 & 0 & 0 & 0 & 0 & 0 & 0 & 1 & 0 & 1 & 0 & 1 & 0 & 0 \\
\hline 1993 & 1 & 0 & 0 & 0 & 0 & 1 & 0 & 0 & 0 & 0 & 0 & 0 & 0 & 0 & 1 & 0 \\
\hline 1994 & 0 & 0 & 0 & 1 & 1 & 0 & 0 & 0 & 0 & 0 & 0 & 0 & 1 & 0 & 0 & 0 \\
\hline 1995 & 0 & 0 & 0 & 0 & 0 & 0 & 0 & 0 & 0 & 0 & 0 & 0 & 0 & 0 & 0 & 1 \\
\hline 1996 & 0 & 1 & 0 & 0 & 0 & 1 & 0 & 0 & 0 & 0 & 0 & 0 & 0 & 1 & 0 & 0 \\
\hline 1997 & 1 & 0 & 1 & 0 & 0 & 0 & 1 & 0 & 0 & 0 & 0 & 0 & 0 & 0 & 1 & 0 \\
\hline 1998 & 0 & 1 & 0 & 0 & 0 & 0 & 0 & 0 & 0 & 0 & 1 & 0 & 0 & 0 & 0 & 1 \\
\hline 1999 & 0 & 0 & 0 & 0 & 0 & 0 & 0 & 0 & 0 & 0 & 0 & 0 & 0 & 0 & 0 & 0 \\
\hline 2000 & 1 & 0 & 0 & 0 & 1 & 0 & 0 & 0 & 1 & 0 & 0 & 0 & 1 & 0 & 1 & 0 \\
\hline 2001 & 0 & 0 & 0 & 0 & 0 & 0 & 0 & 0 & 0 & 0 & 0 & 0 & 0 & 0 & 0 & 0 \\
\hline 2002 & 0 & 0 & 0 & 0 & 0 & 0 & 0 & 0 & 0 & 0 & 0 & 0 & 0 & 0 & 0 & 0 \\
\hline
\end{tabular}

Upswings and Downswings (1=upswing; -1=downswing)

\begin{tabular}{|c|c|c|c|c|c|c|c|c|}
\hline & $\begin{array}{l}\text { Real GDP } \\
\end{array}$ & Fin. sector real value added & Euro area Real GDP & Euro area Dow Jones $2 /$ & BEDEFR asset prices 4/ & World asset prices 5/ & GG balance/GDP 3/ & Central govt. revenue \\
\hline & state & state & state & state & state & state & state & state \\
\hline 1987 & 1 & 1 & 1 & 1 & -1 & -1 & & \\
\hline 1988 & 1 & 1 & 1 & 1 & -1 & -1 & & \\
\hline 1989 & -1 & 1 & -1 & 1 & 1 & -1 & & \\
\hline 1990 & -1 & -1 & -1 & -1 & -1 & -1 & 1 & \\
\hline 1991 & 1 & -1 & -1 & -1 & -1 & -1 & -1 & 1 \\
\hline 1992 & 1 & 1 & -1 & 1 & -1 & -1 & -1 & 1 \\
\hline 1993 & 1 & -1 & -1 & 1 & 1 & 1 & 1 & 1 \\
\hline 1994 & -1 & -1 & 1 & 1 & 1 & 1 & 1 & -1 \\
\hline 1995 & -1 & 1 & -1 & 1 & 1 & 1 & -1 & -1 \\
\hline 1996 & -1 & 1 & -1 & 1 & 1 & 1 & -1 & 1 \\
\hline 1997 & 1 & 1 & 1 & 1 & 1 & 1 & 1 & 1 \\
\hline 1998 & -1 & -1 & 1 & -1 & 1 & 1 & 1 & -1 \\
\hline 1999 & 1 & -1 & 1 & -1 & 1 & -1 & 1 & 1 \\
\hline 2000 & 1 & -1 & 1 & -1 & 1 & -1 & 1 & 1 \\
\hline 2001 & -1 & -1 & -1 & -1 & -1 & -1 & -1 & -1 \\
\hline 2002 & -1 & -1 & -1 & -1 & -1 & -1 & -1 & -1 \\
\hline
\end{tabular}

Sources: IMF, WEO; Datastream; Jaeger and Schuknecht (2003); and IMF staff estimates.

1/ Annual growth rates; all data are in real rather than nominal terms, unless otherwise noted.

$2 /$ Index in nominal terms.

3/ Ratio to GDP, not annual growth rate; variables in nominal terms.

4/ Refers to Belgium, France, and Germany real asset prices average.

5/ Refers to BEDEFR plus the U.K. and U.S. real asset prices average. 
Figure I-1. Luxembourg: Recent Economic Developments, 1985-2003 (In percent)
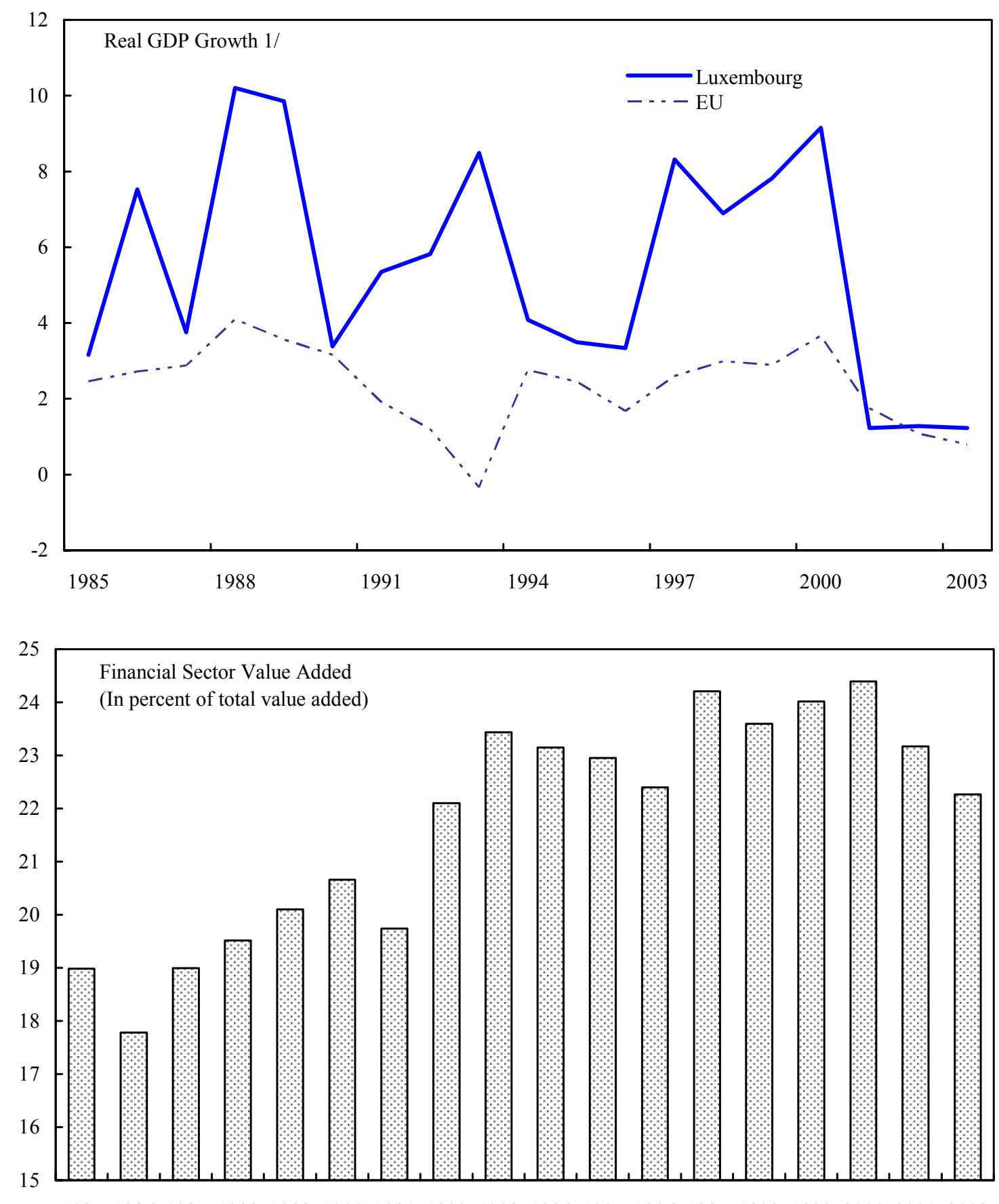

198519861987198819891990199119921993199419951996199719981999200020012002

Sources: STATEC; IMF, World Economic Outlook; and Bloomberg.

1/ Data for 2003 are IMF staff estimates. 
Figure I-2. Luxembourg: Equity Markets and Asset Prices, 1985-2003

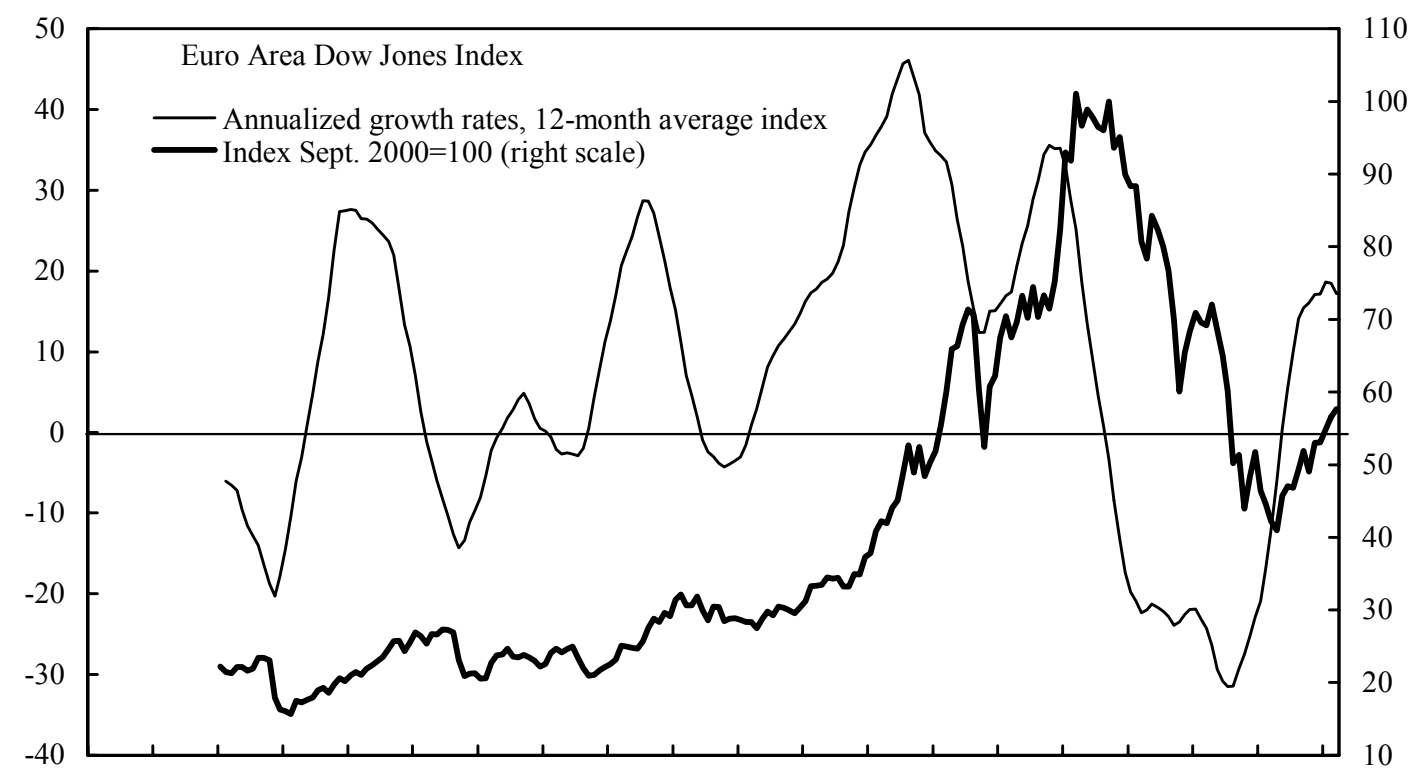

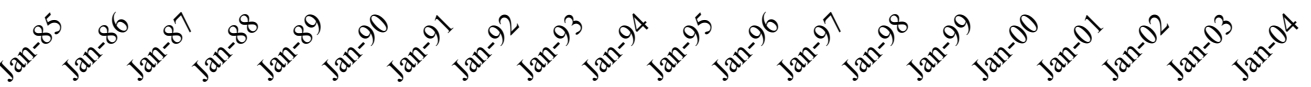

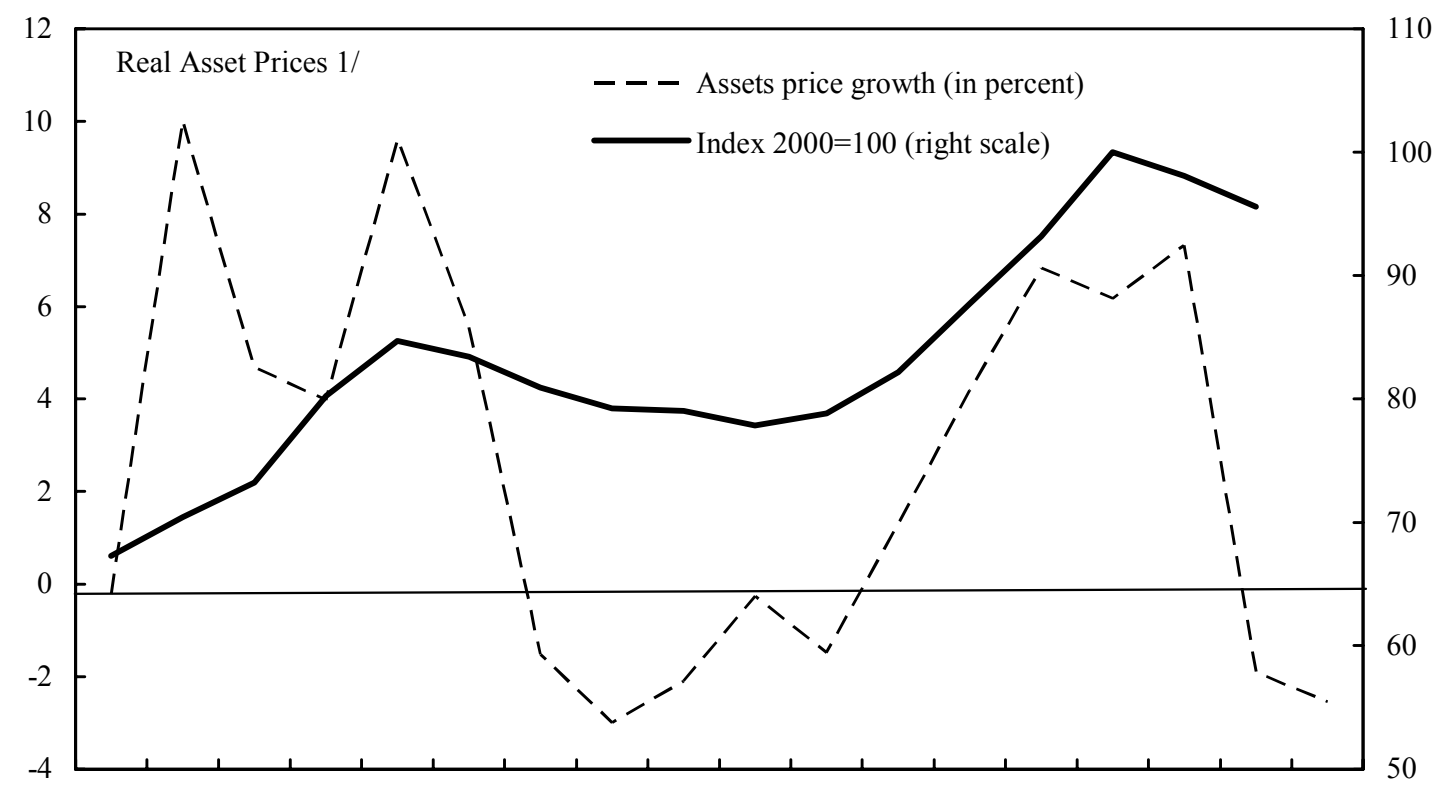

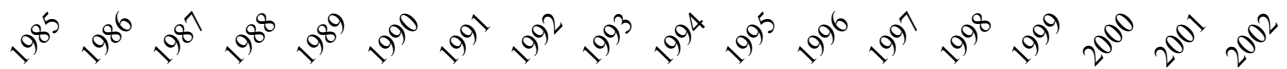

Sources: Datastream; Jaeger and Schuknecht (2003); and IMF staff estimates.

1/ Average of Belgium, France, and Germany. 
Figure I-3. Luxembourg: Actual and Trend Real GDP Growth Rates, 1961-2002 (In percent)
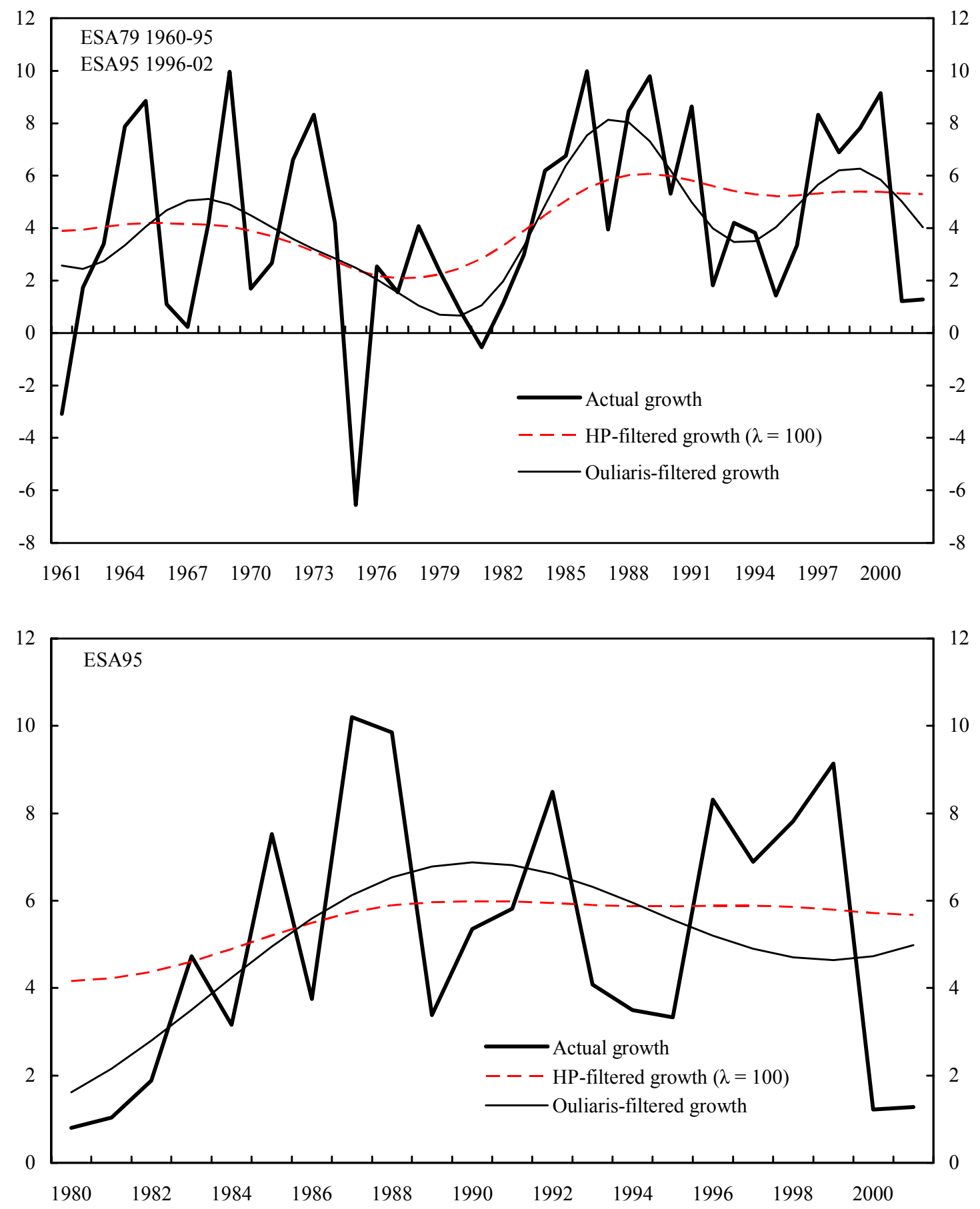

Sources: STATEC; IMF, World Economic Outlook; and IMF staff estimates. 
Figure I-4. Luxembourg: Actual and Trend Labor Productivity Growth Rates, 1980-2002 (In percent)
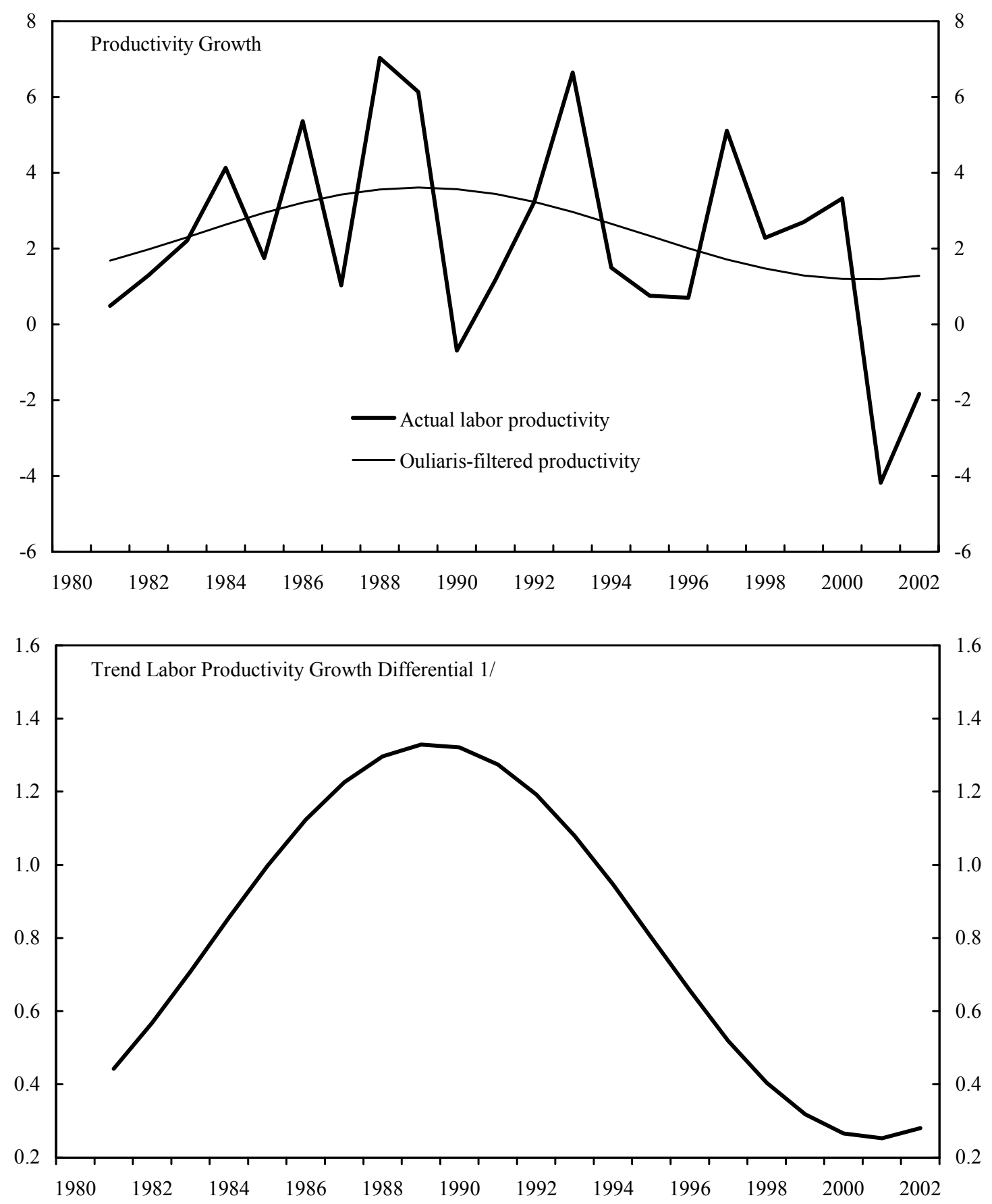

Sources: STATEC; IMF, World Economic Outlook; and IMF staff estimates.

1/ Differentials from output-weighted average productivity level for Germany, France and Belgium. 
Figure I-5. Luxembourg: Labor Market Developments, 1985-2003 (In percent)
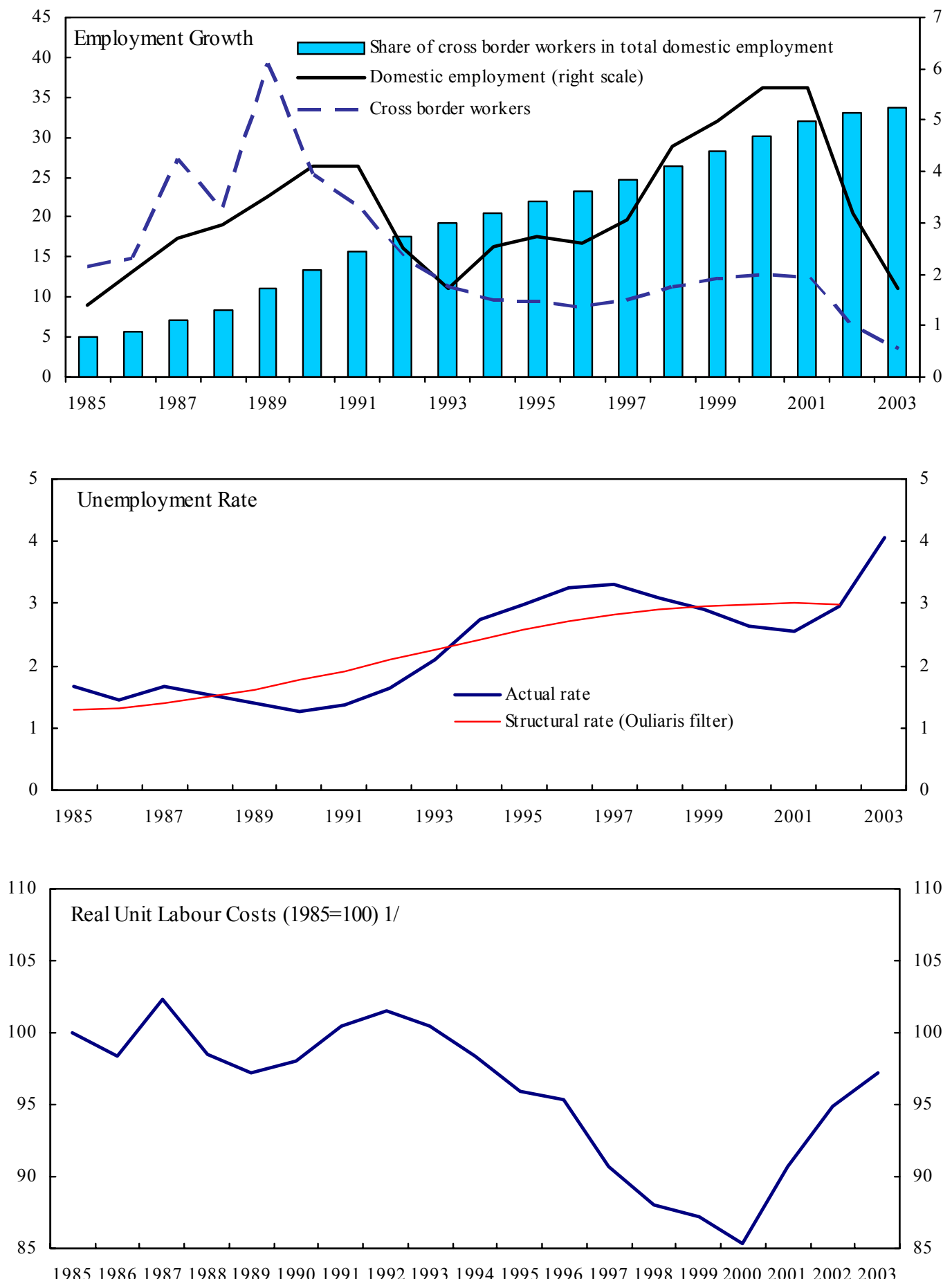

Sources: STATEC; Eurostat; IMF, World Economic Outlook; and IMF staff estimates.

1/ Data for 2003 are IMF staff estimates. 
Figure I-6. Lead-Lag Relations: Asset Prices, Financial Sector, and General Government Deficit, 1990-2002 1/
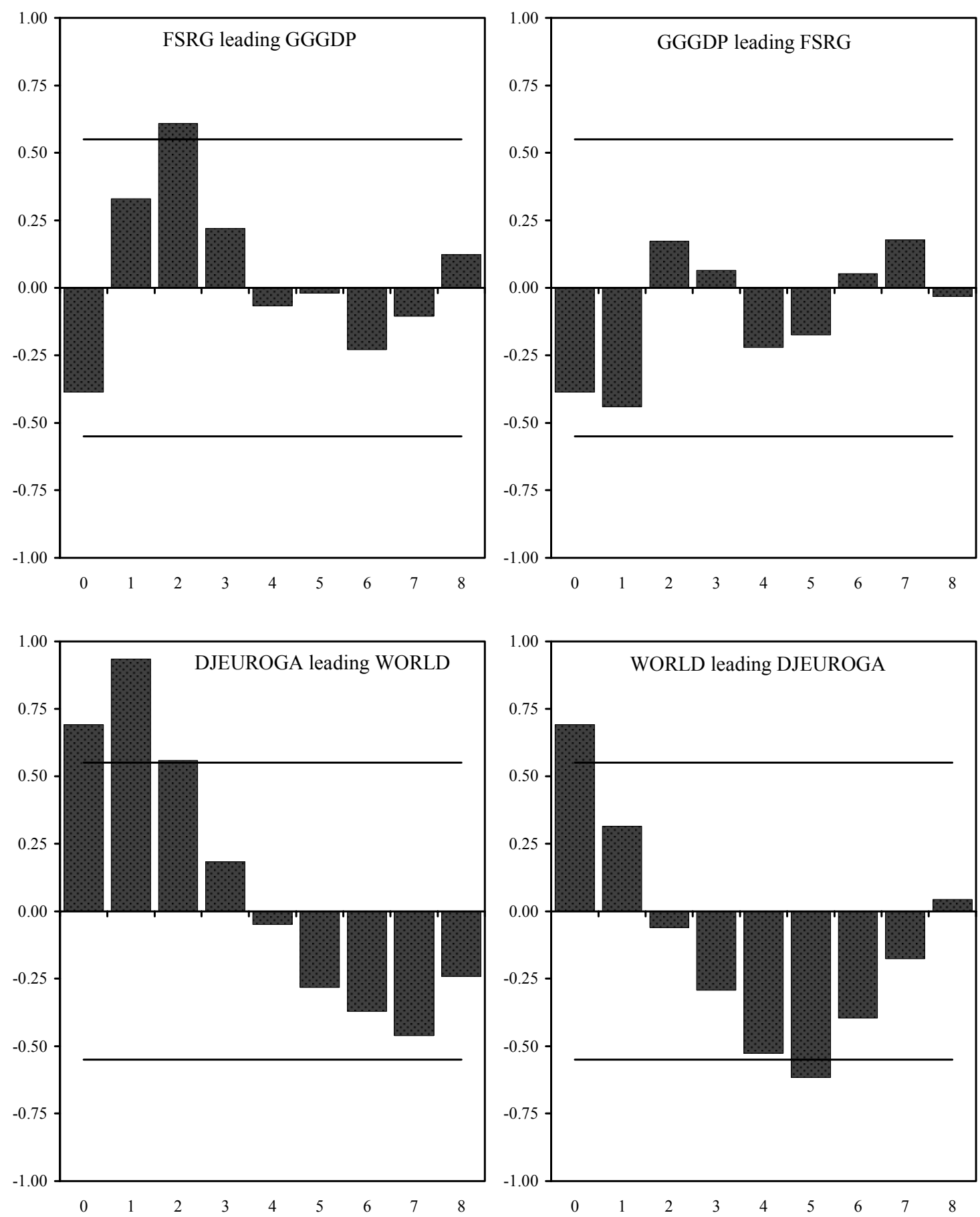

Sources: STATEC; Eurostat; IMF, World Economic Outlook; and IMF staff estimates. $1 /$ FSRG stands for real value added in the financial sector; GGGDP for the general government budgetary balance (in percent of GDP); DJEUROGA for the DJ Euro Stoxx index; and WORLD for an index of world real asset prices. The horizontal lines delimit a 95 percent confidence interval. 


\section{References}

Blanchard, O. and D. Quah, 1989, "The Dynamic Effects of Aggregate Demand and Supply Disturbances," The American Economic Review, 79, pp. 655-73.

Cogley, T. and J. Nason, 1995, "Effects of the Hodrick-Prescott Filter on Trend and Difference Stationary Time Series: Implications for Business Cycles," Journal of Economic Dynamics and Control 19, pp. 235-278.

Harding, D. and A. Pagan, 2002, "Dissecting the Cycle: A Methodological Investigation," Journal of Monetary Economics, Vol. 49, pp. 365-81.

Hodrick, R. J. and E.C. Prescott, 1997, "Post-War U.S. Business Cycles: An Empirical Investigation," Journal of Money, Credit, and Banking, Vol. 29, pp. 1-16.

Jaeger, A. and L. Schuknecht, 2003, “Asset Price Cycles and Fiscal Policy Behavior,” IMF, mimeo.

Keynes, J. M. (1936). The General Theory of Employment, Interest, and Money, London, MacMillan.

Kim, C-J. and C. R. Nelson (1999). "Friedman's Plucking Model of Business Fluctuations: Tests and Estimates of Permanent and Transitory Components," Journal of Money, Credit, and Banking, pp. 1-22.

King, R. G., and S. T. Rebelo, 1993, "Low Frequency Filtering and Real Business Cycles," Journal of Monetary Economics, Vol. 33, pp. 405-38.

Nadal De Simone, F., 2002, "Common and Idiosyncratic Components in Real Output: Further International Evidence,” IMF Working Paper 02/229.

Neftcy, S. N. (1984). "Are Economic Time Series Asymmetric over the Business Cycle?," Journal of Political Economy 92, pp. 307-28.

Ouliaris, S., 2001, “On Extracting Business Cycles From Nonstationary Data,” International Monetary Fund, manuscript.

Ramsey, J. and P. Rothman (1996). "Time Irreversibility and Business Cycle Asymmetry," Journal of Money, Credit, and Banking 28, pp.1-21.

Razzak, W. A. (2001). "Business Cycles Asymmetries: International Evidence," Review of Economic Dynamics 4, pp. 230-43.

Sichel, D. E. (1993). "Business Cycle Asymmetry: A Deeper Look", Economic-Inquiry, pp. 224-36. 


\section{Pension System Projections and Policy Options 16}

\section{A. Introduction and Summary}

31. The pension system has developed well thus far but it remains a potential source of vulnerability. The pay-as-you-go (PAYG) pension system has accumulated significant assets and offers high income replacement rates to a full career pensioner. However, the system remains vulnerable on two fronts. First, population aging will put pressure on pension expenditures. If these are met by levying higher contributions, the country's economic growth performance might suffer. Second, large shocks can adversely affect the flow of commuters and immigrants to Luxembourg - commuters alone already account for about one third of the labor force - thereby potentially causing a vicious circle of falling output and employment and rising contribution rates.

32. The vulnerabilities and related issues were discussed in previous Article IV consultations, with staff projections suggesting that high real GDP growth rates were required to sustain the present system over the long run. ${ }^{17} \mathrm{~A}$ key finding was that the current contribution and income replacement rates can be jointly maintained only if annual real GDP growth averages about 5 percent through $2050 .{ }^{18}$ While such a growth rate would be in line with output growth over 1980-2000, Chapter I argued that growth prospects are presently very uncertain for various reasons, notably the long duration of the current slowdown and an ongoing decline in productivity growth.

\section{A long-standing Fund staff recommendation is for Luxembourg to consider} developing a mandatory, fully-funded pension pillar because of its mobile contributions base. The public sector assets - which amount to close to 60 percent of GDP — could be used to that effect. ${ }^{19}$ The reason is that such a pillar offers a measure of protection against significant economic shocks, to which Luxembourg is more formally exposed than most countries because of its highly mobile workforce. Such a pillar has not been developed thus far. However, (i) private retirement saving has recently been fostered with tax incentives; (ii) abuse of early retirement schemes has been reduced; and (iii) public sector assets have been accumulated.

34. An option for reforming the PAYG pension pillar would be to link pension benefits to the contributions base, through a "solidarity factor," as argued in the staff report (SM/04/113, 04/07/04, Box 3). Following a brief review of updated long-run pension

${ }^{16}$ Prepared by Jean-Luc Annaert and Francisco Nadal De Simone.

${ }^{17}$ For example, see IMF Staff Country Reports No. 00/67 and No. 02/118

${ }^{18}$ See IMF Staff Country Reports No. 02/118, Box 1.

${ }^{19}$ For example, see Public Information Notices No. 00/34 and No. 02/61. 
projections, this chapter explains how such a factor would work. Section A presents the basic features of the pensions system; Section B develops the updated projections; and Section C discusses the "solidarity factor." The updated pensions projections in Section B show only slightly higher expenditure than those in IMF Staff Country Reports No. 02/118, Box 1. The small differences reflect new data.

35. The results suggest that by (i) formally linking pension benefits to developments in the contributions base through the "solidarity factor," and (ii) simultaneously linking the statutory retirement age to life expectancy, relatively generous income replacement rates could be sustained over the long run, even with (by historical standards) relatively low real GDP growth (just under 2 percent per annum). More importantly, these measures would signal economic agents that contribution rates would be kept in check even as the population ages or as the economy suffers shocks. This signal would help sustain the inflow of capital and workers and thereby forestall potentially more drastic measures in the future. Furthermore, the "solidarity factor" can ensure a more gradual adjustment in replacement and contribution rates than the present system, which relies on reviews and, if deemed necessary, adjustments of these rates every seven years.

\section{B. The Basic Features of the Pensions System ${ }^{20}$}

\section{Retirement income is provided mainly by a mandatory PAYG public pension} pillar that counts among the most generous in the OECD. By law, everyone in gainful employment must be affiliated with the PAYG general pension scheme. ${ }^{21}$ This scheme is financed through a contribution from wages of 24 percent, which is paid in equal shares by employers, employees, and the State budget. The contribution rate is determined for a period of seven years and the next reevaluation is scheduled for 2006. A reserve that has to be equivalent to a least 1.5 times the annual amount of benefits serves to ensure a stable contribution rate between reevaluations. The net replacement rates for a full insurance career under the general scheme are high, reaching almost 100 percent for blue collar workers. In fact, the average replacement rate is much lower, amounting to some 70 percent, because many workers (notably commuters) never reach a full insurance career. Box II-1 describes the specific features of the pension system.

\footnotetext{
${ }^{20}$ For further information, please see IGSS, 2003, The Luxembourg Pension System and IGSS, 2003, Droit de la securité sociale.

${ }^{21}$ In addition to the general PAYG pension system two further insurance systems exist: supplementary pension schemes offered by companies; and private pensions plans contracted by individuals. The PAYG scheme accounts for the vast majority of all pension benefit payments.
} 
37. For several reasons many individuals exit the workforce well before reaching the statutory retirement age of 65 years. The labor force participation rate of men aged 55-64 years amounts to merely 38 percent. First, about one third of all new pensions are for

\section{Box II-1. Key Features of the Pension System}

The normal retirement age is 65 years but many retire at a younger age because the pension system is not actuarially fair. A person may retire at age 60 if he has been insured for at least 480 months, of which 120 months under the compulsory insurance scheme; or at age 57 years with at least 480 months under the compulsory scheme.

\section{Pension benefits are a function of several elements:}

- A flat element: for a total insurance period of 480 months, a pensioner receives a monthly amount equivalent to $€ 489.98$; if he has been insured for less than 480 months, this amount is reduced proportionally.

- An element proportional to income: the pensioner will receive a yearly amount equal to 1.85 percent of his total professional income during his insurance period. To determine this part of the pension, all contributable wages and incomes are calculated at the wage and price level of the base year 1984, then they are summed up to be multiplied by (i) an index that takes into account the evolution of prices since 1984; (ii) an adjustment factor that takes into account the evolution of the general wage level at constant prices.

- A staggered increase in the element proportional to income: in order to encourage continued work, for the persons who have reached 55 years and who have an insurance period of at least 38 years, the 1.85 percent coefficient is increased for the additional years of activity by 0.01 percentage point per year of age and by 0.01 percentage point per year of insurance, but by no more than 0.2 percentage point in total.

Furthermore, (i) pensions are subject to income tax and health care contributions totaling some 3.55 percent; (ii) they are indexed to consumer prices and are automatically increased by 2.5 percent every time this index has risen by the same amount; (iii) they are adjusted every two years to the increase in wages and salaries relative to prices but this must be decided by a law; and (iv) no pension may currently be lower than $€ 1,263.88$ per month or higher than $€ 5,846.66$ per month. 
disability. ${ }^{22}$ Measures have been taken to curtail the abuse of disability pensions. Second, when firms need to downsize or adapt their labor force various early retirement schemes are available for workers aged at least 57 years. And third, incentives to continue working until the statutory retirement age are low under the regular pension scheme. For example, take an individual who has begun work in 1963 at age 18 and who typically has earned an amount equivalent to about $1 \frac{1 / 2}{2}$ times the guaranteed monthly minimum income (RMG), which in 2003 stood at euro 1,386. This worker can retire at age 57 on a gross replacement rate of 87 percent (Figure II-1).

\section{Updated Projections}

\section{Basic framework and assumptions}

38. The official demographic projections produced by STATEC show a considerable aging of the resident population. According to these projections, the total resident population would increase by 1 percent through 2050: it would start at about 449,000 in 2003 , reach a maximum of about 463,000 around 2030 , and then fall again to about 453,000 by 2050 . The number of individuals who are older than 60 years currently amounts to about 33 percent of the number who are 20-59 years old - this ratio almost doubles, reaching 61 percent by 2050 (Figure II-2).

\section{Other assumptions underlying all scenarios concern the employment rate of residents and technological progress:}

- The rate of employment of the resident population aged 20-59 years is assumed constant at its 2003 level of close to 76 percent. Consequently, resident employment evolves in line with the resident population aged 20-59. Similarly, the unemployment rate is assumed to remain constant.

- Labor-augmenting technological progress proceeds at a rate of 2 percent per annum.

- For simplicity, changes to the contribution and replacement rates - when necessary to balance the pension system - are assumed to set in only once the current pension reserve is fully exhausted. This can give rise to sudden changes in these rates that, in practice, could be phased in, in line with current regulation.

40. Two simulations capture the important role of commuters for the evolution of the pension system:

${ }^{22}$ If the disability pension recipient is less than 50 years old he must undergo rehabilitation or retraining measures, unless recommended otherwise by medical counsel. Disability pensions are transformed into old-age pensions at age 65 . 
- $\quad$ Simulation A: This simulation assumes 5 percent real GDP growth (on average) during 2005-50, a rate comparable to that recorded during 1980-2000. With 2 percent labor augmenting technological progress and a broadly unchanged resident population, a continuous inflow of commuters is needed to sustain such a growth rate-labor supply by nonresidents is thus the endogenous variable. Total employment increases by about 3 percent annually, reaching nearly 1.2 million in 2050. As a result, the ratio of employed commuters to residents rises from about 0.5 in 2003 to 6 in 2050 (Figure II-2).

- Simulation B: This simulation differs from the previous one in that the amount of commuters is frozen at the level projected for 2005 in Simulation A. Real GDP growth averages somewhat less than 2 percent annually during 2005-50, driven by labor-augmenting technological progress.

\section{Main simulation results}

41. Under simulation A-which assumes 5 percent real GDP growth annually-the current contribution and benefit replacement rates can be jointly sustained. The ratio of the number of pensioners to the number of employed stays broadly unchanged at about one third (Figure II-3). Thus, the rise in GDP and employment is strong enough to stabilize pension expenditure at around its current level of about 11 percent of GDP. The contribution rate that would balance contributions and revenues from assets with pension expenditure remains broadly unchanged at about 21 percent, sustaining an average replacement rate of about 70 percent (Figure II-4).

\section{Under simulation B-which generates just under 2 percent real GDP growth} annually - the current contribution and replacement rates cannot be jointly sustained. The ratio of the number of pensioners to the number of employed doubles to over 70 percent (Figure II-3). With the current contribution and income replacement rates the pension reserve would be exhausted in 2014. Today's 24 percent contribution rate could sustain only a gradually declining replacement rate that reaches less than half its present level in 2050; alternatively, pension expenditure would more than double to about 24 percent of GDP in 2050 , requiring an increase in the contributions rate to about 50 percent (Figure II-4). However, such an increase in the contribution rate could undermine employment and output growth, potentially pushing the economy into a vicious circle of rising contribution rates and falling activity.

43. The simulation results underscore that a continued, strong inflow of commuters is needed to sustain the pension system, otherwise deleterious hikes in contribution rates might be necessary. The results from the simulations are very similar to those obtained in previous Fund staff reports but the growth outlook is now much more uncertain (Chapter I). ${ }^{23}$ Obviously, contribution rates, replacement rates, and commuting are all

${ }^{23}$ See IMF Staff Country Reports No. 00/67 and No. 02/118, Box 1. 
interdependent: high contribution rates deter commuting and job creation; high pension benefits may attract commuters. This interdependence, which has not been modeled here, can be a source of vulnerability both for the pensions system and the economy.

\section{Reform Options}

\section{Various options can be considered to strengthen the robustness of the pension} system and the economy to shocks. Luxembourg is particularly exposed to such shocks because of the openness of its economy, notably the high mobility of factors of production. ${ }^{24}$ A key recommendation in previous Article IV consultations has been for the authorities to consider developing a mandatory, fully-funded pension pillar to strengthen the robustness of the pension system to shocks. Such a pillar is obviously attractive because of Luxembourg's mobile workforce. However, the likelihood of vicious circles of rising contribution rates and falling employment and output growth — be it in response to rising pension expenditure over time large or large adverse shocks — can also be lowered with other measures. Two such measures are considered here: (i) raising the retirement age in line with life expectancy; and (ii) linking pension benefits to the contributions base through a "solidarity factor." The effectiveness of these measures is gauged under the employment and real GDP conditions of simulation B.

- $\quad$ Simulation C: This simulation maintains the assumptions of Simulation B but also considers an increase in the statutory retirement age. Specifically, while real GDP grows by just under 2 percent annually, the retirement age is increased monotonically by about five years starting in 2015 , or by about $1 \frac{1}{4}$ years per decade. The contribution rate is kept unchanged, while pensions benefits and thus the replacement rate balance the system. As a result, the replacement rate declines to about 40 percent in 2030 to then recover to nearly 50 percent in 2050 (Figure II-5). This compares to an equilibrium replacement rate of about 33 percent from 2030 onward if the retirement age was left unchanged.

- $\quad$ Simulation D: This is the same as Simulation C but with the contribution rate increased from 24 percent to 30 percent in 2015-in practice, such an increase would probably be phased in but this does not undermine the analysis presented here. Again, the contribution rate is kept unchanged while pension benefits and thus the income replacement rate balance the system: the replacement rate falls to about 50 percent in 2030 but then rises again to about 62 percent in 2050 (Figure II-5). Notice that raising the contribution rate by 1 percentage point allows an increase in the equilibrium replacement rate by about 2 percentage points. Thus, raising the contribution rate by only $2^{1 / 2}$ percentage points in 2015 would permit attaining a replacement rate of about 55 percent in 2050 .

${ }^{24}$ See also Chapter I. 
45. The combination of a higher retirement age and limited adjustments in the contributions rate would allow the pension system to sustain a healthy replacement rate, even with a real GDP growth rate that is low by historical standards. With 2 percent real GDP growth and a contribution rate hike 6 percentage points in 2015, the average replacement rate would drop by about 10 percent; if the contribution hike were limited to a less-damaging $2 \frac{1}{2}$ percentage points, the average replacement rate would fall by about 20 percent. For the typical pensioner with a full insurance career-whose current income replacement rate likely is between 90-100 percent - the replacement rate would thus remain at a healthy level, even with the smaller increase in the contribution rate.

46. The idea behind linking pension benefits to the contributions base-through a "solidarity factor" - is that the burden of adjusting to aging and shocks would be shared between retirees and workers. In that sense, such a link serves to cement the solidarity between generations. More specifically, pension benefits $\mathrm{P}$ could be determined as follows:

$P_{t}=P_{t-1} * \frac{C P I_{t-1}}{C P I_{t-2}} * \frac{W_{t-1}}{W_{t-2}} * S_{t}$, where $S_{t}=\left(1-\frac{R_{t-1}}{R_{t-2}}\right) * \alpha+1, R_{t}=\frac{N P_{t}}{N W_{t}}$

Here CPI denotes the consumer price index; W the wage index that captures the evolution of wages relative to prices; S denotes the "solidarity factor," and R denotes the ratio of the number of "equivalent" pensioners NP (the number of pensioners divided by the standard full career pension) and the number of "equivalent" wage earners NW (the total wage bill divided by the average wage). The coefficient $\alpha$ determines the extent to which changes in the oldage dependency ratio lead to changes in pension benefits or changes in contribution rates, which have to balance the pension system. The coefficient $\alpha$ could either be fixed or determined endogenously, given a fixed ceiling on the contribution rate. If a ceiling on the contribution rate was adopted and the statutory retirement age was linked to life expectancy, the conditions would be as under Simulation D.

47. A link between the pension benefits and the contributions base has recently been established in one of Luxembourg's neighboring countries, Germany. Following the March 2004 reform, pensions in Germany are adjusted as a function of the change in the relation between the number of "equivalent" pensioners and "equivalent" contributors, very much as suggested in the formula above. Under the German pension formula, an x percent worsening in this ratio would lead to a $0.25^{*} \mathrm{x}$ percent reduction in the pension, other things equal $(\alpha=0.25)$.

48. One avenue to strengthen the country's resilience to shocks is thus to formally link the statutory retirement age to life expectancy and the replacement rate to the contributions rate. Such a reform is appealing for several reasons. First, it would signal a determination to maintain the country's attractiveness for workers and investors, thus foster a continued expansion of the revenue base, and thereby potentially forestall the need for more drastic measures in the future. Put simply, if economic agents know that - despite an aging 
resident population - contribution rates will remain fairly stable under a broad range of economic growth scenarios, human and physical capital will continue to flow into Luxembourg. This, in turn, would allow healthy replacement rates to be maintained. Second, if appropriately designed, such a reform leads to gradual adjustments of pensions benefits and thus income replacement rates in response to population aging. The current system of reviews every seven years might entail more abrupt changes, given the requirement to set rates with a view to maintaining reserves at about 1.5 times the level of annual pension payments. It might also be less forward looking.

49. Clearly, the implications of linking benefits to the contribution base would have to be explained to economic agents. In particular, agents would have to understand that different economic growth rates would entail different pension benefits and thus income replacement rates. They could then make informed decisions about private retirement savings, including under the recently-enhanced "third pillar." In the meantime, a continued accumulation of assets could serve later to protect the pensions of the most vulnerable segments of the population from major downward adjustments. 
Figure II-1. Luxembourg: Pension Benefit Replacement Rate (In percent of wage)

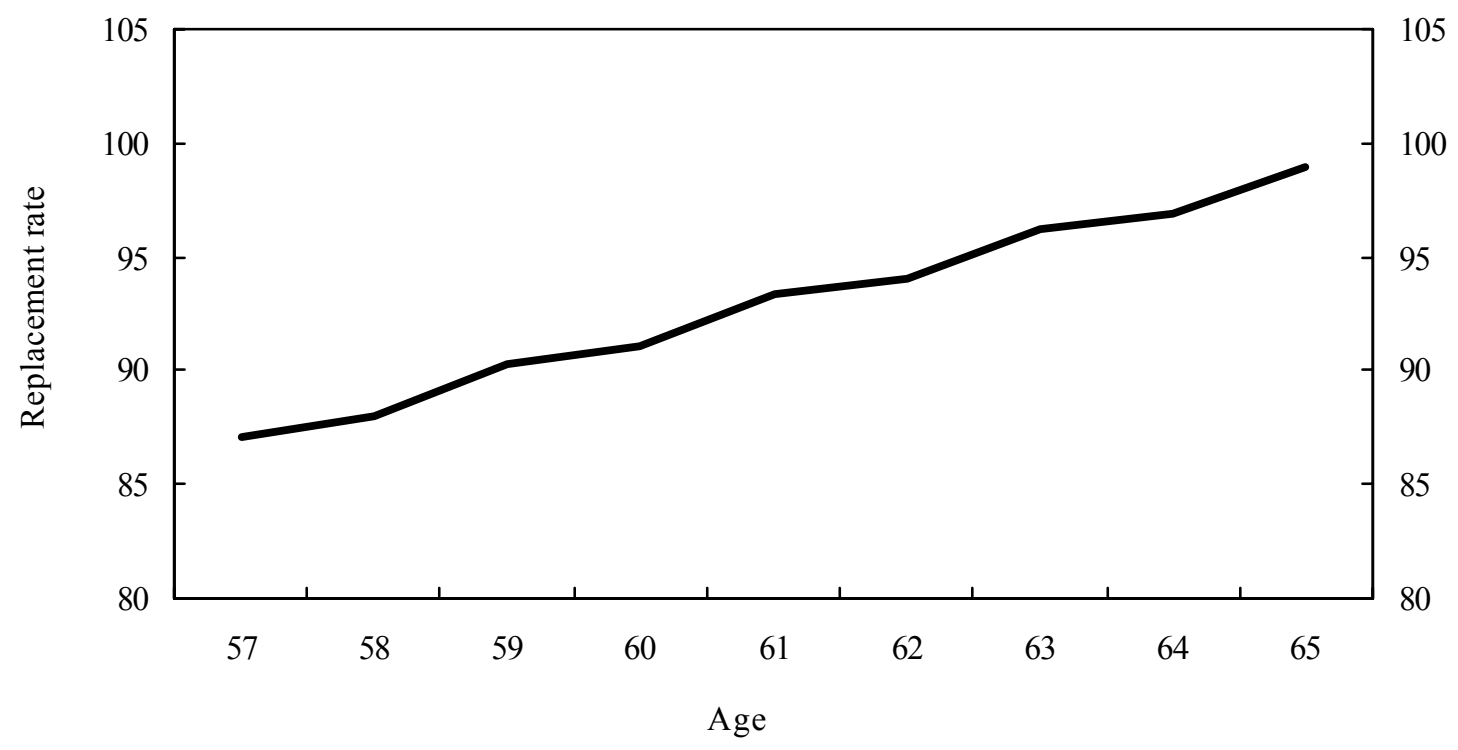

Sources: IGSS; and IMF staff estimates. 
Figure II-2. Luxembourg: Population Aging and Crossborder Workers, 2003-2050
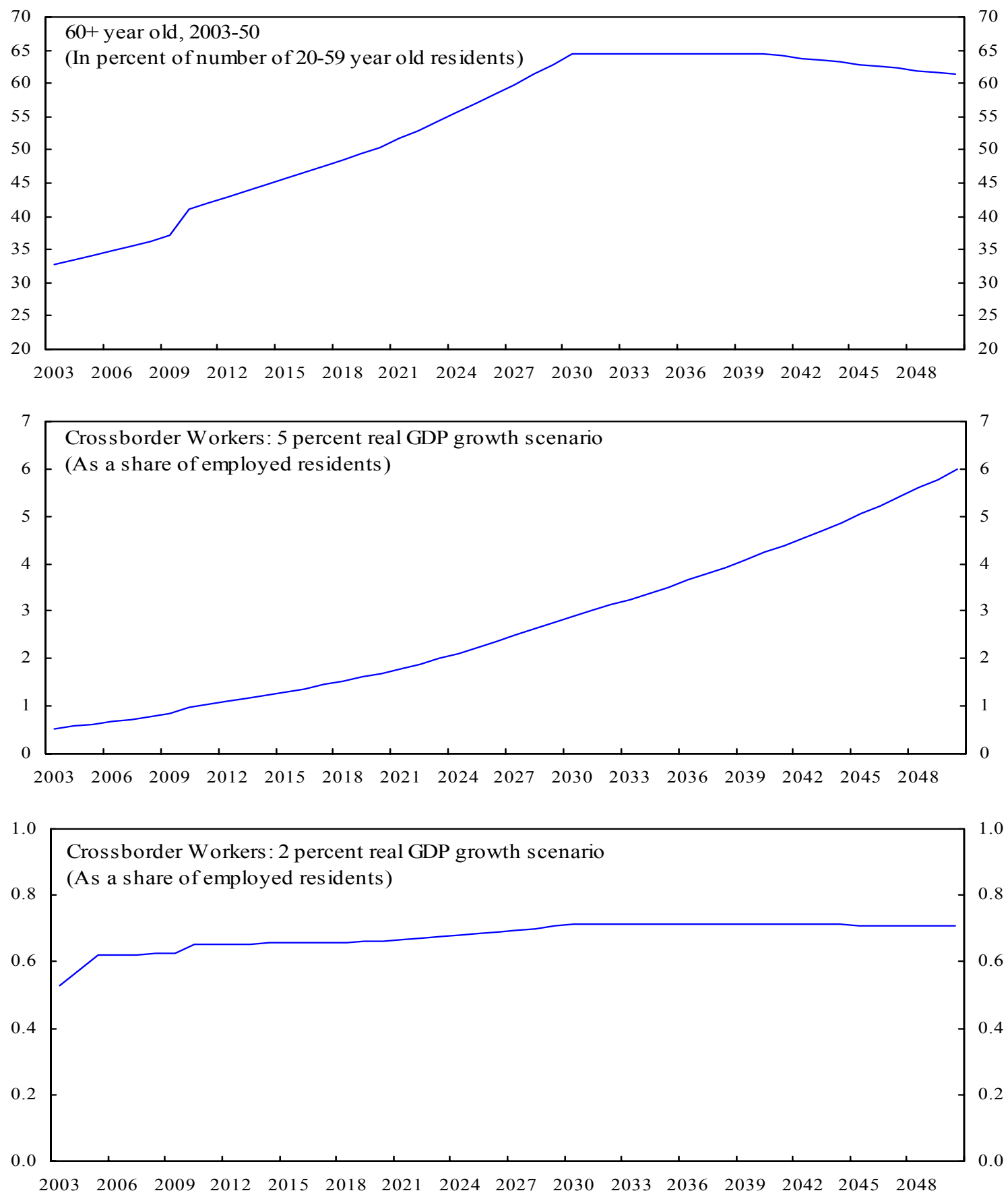

Sources: IGSS; and IMF staff estimates. 
Figure II-3. Luxembourg: The Ratio of Pensioners to Workers, 2003-2050 (In percent)
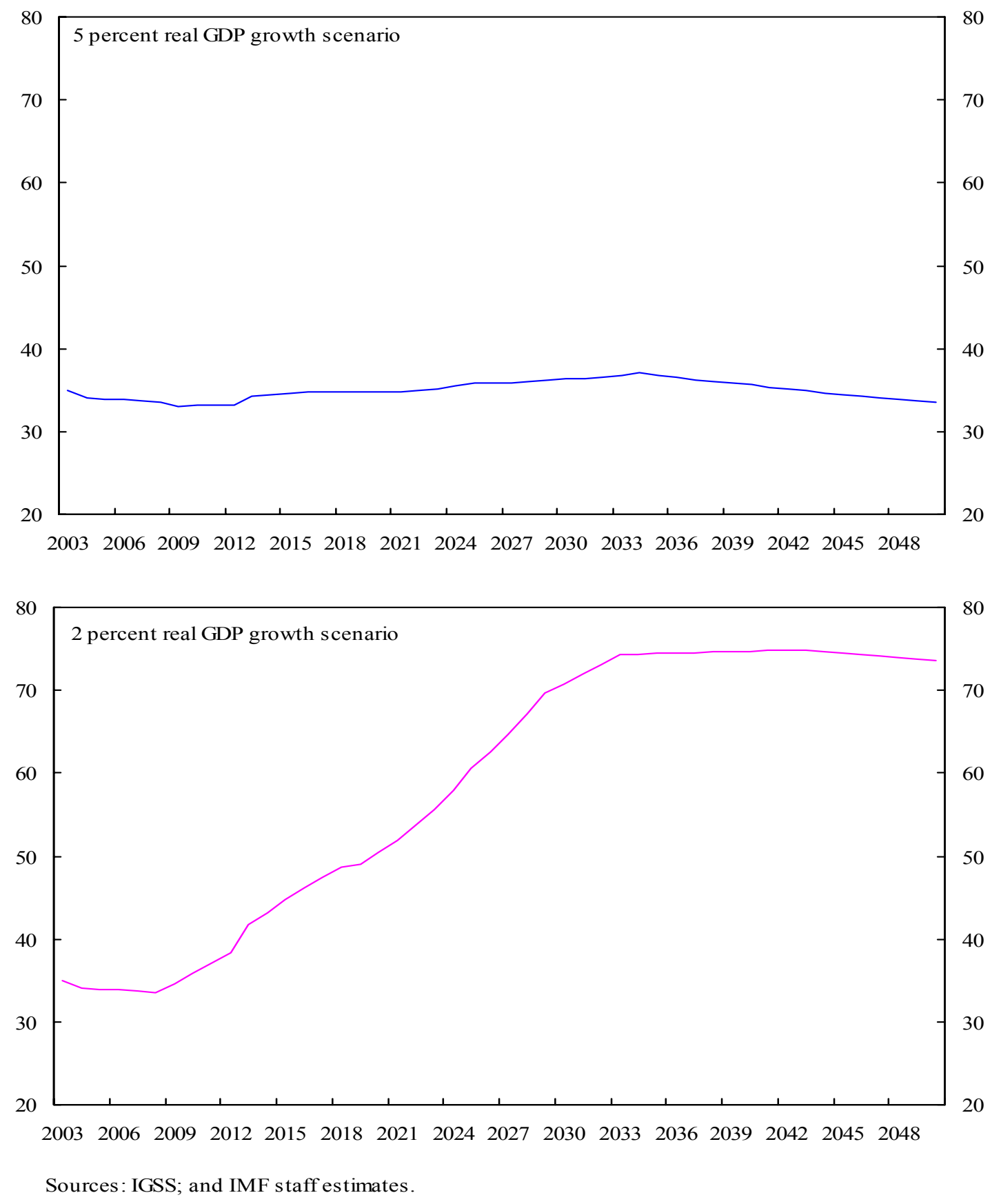
Figure II-4. Luxembourg: Pension Replacement and Contribution Rates, 2003-2050 (In percent)
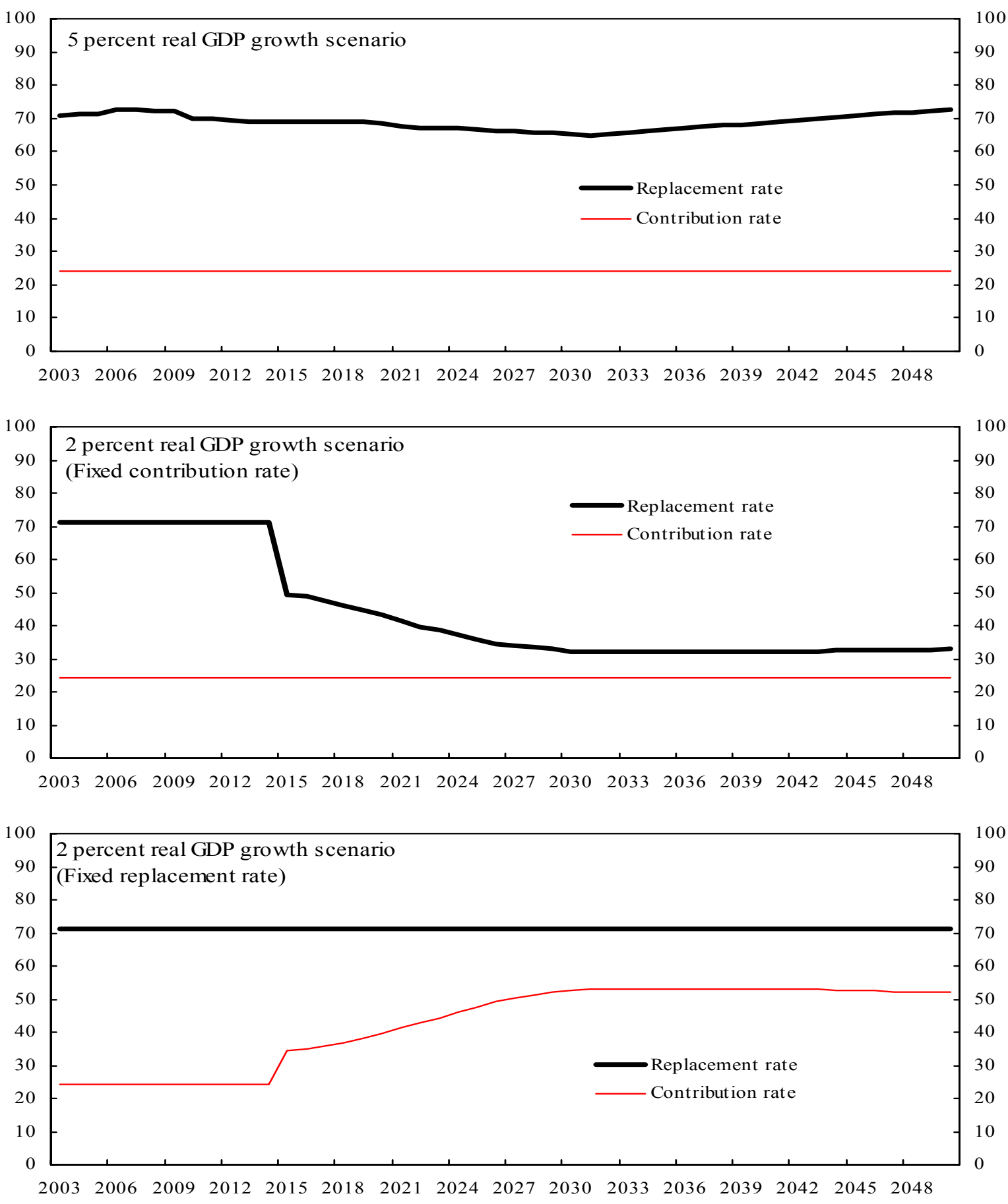

Sources: IGSS; and IMF staff estimates. 
Figure II-5. Luxembourg: Pension Replacement and Contribution Rates, 2003-2050 Two Percent Real GDP Growth Scenario
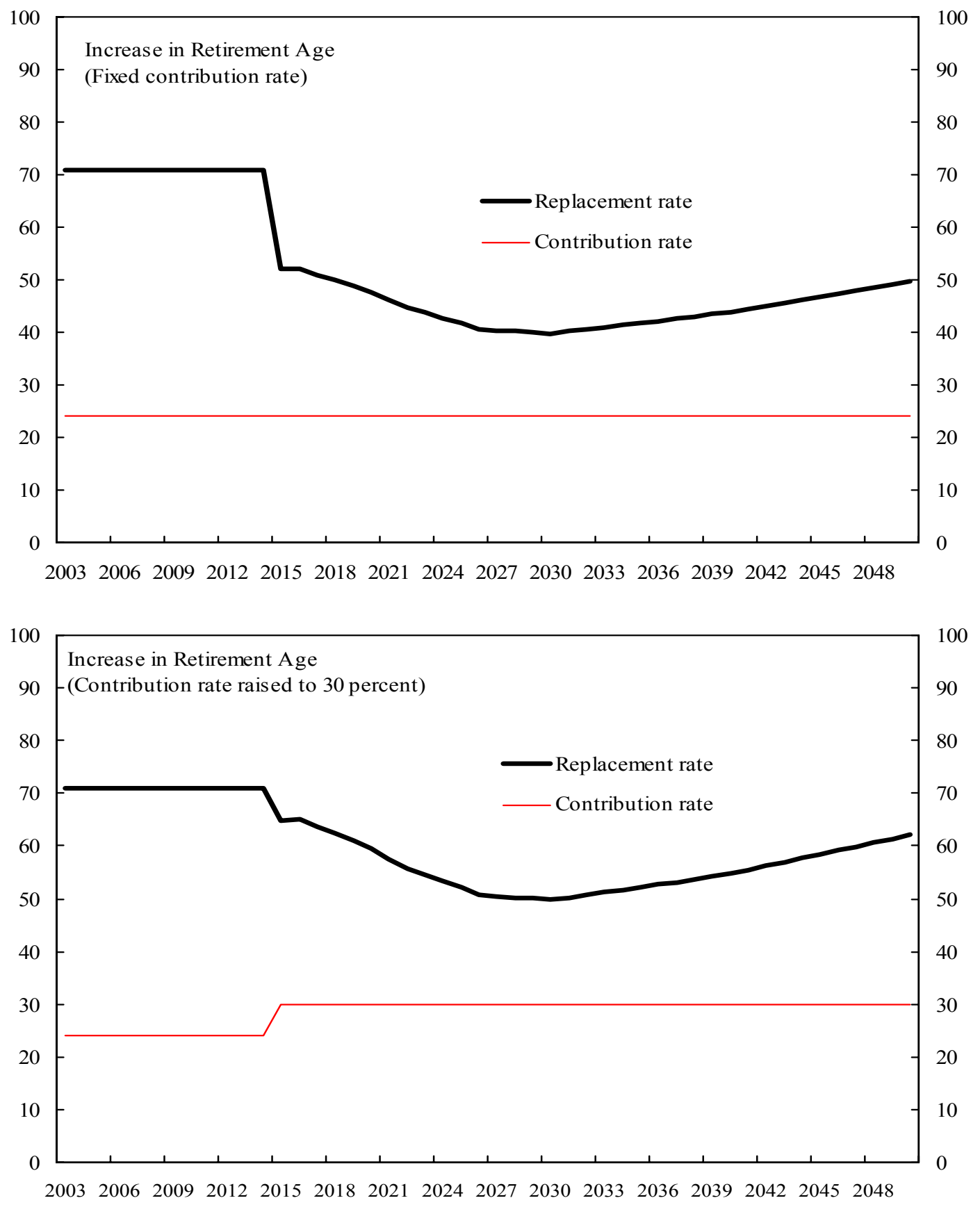

Sources: IGSS; and IMF staff estimates. 